\title{
GABA and glutamate transporters in brain
}

\section{Yun Zhou and Niels Christian Danbolt*}

The Neurotransporter Group, Department of Anatomy, Institute of Basic Medical Sciences, University of Oslo, Oslo, Norway

\section{Edited by:}

Leif Hertz, China Medical University, China

Reviewed by:

Leif Hertz, China Medical University, China

Fiorenzo Conti, Università Politecnica delle Marche, Italy

\section{*Correspondence:}

Niels Christian Danbolt, The

Neurotransporter Group, Department of Anatomy, Institute of Basic Medical Sciences, University of Oslo, P.O. Box 1105 Blindern, Oslo N-0317, Norway e-mail: n.c.danbolt@medisin.uio.no
The mammalian genome contains four genes encoding GABA transporters (GAT1, slc6a1; GAT2, slc6a13; GAT3, slc6a11; BGT1, slc6a12) and five glutamate transporter genes (EAAT1, slc1a3; EAAT2, slc1a2; EAAT3, slc1a1; EAAT4, slc1a6; EAAT5, slc1a7). These transporters keep the extracellular levels of GABA and excitatory amino acids low and provide amino acids for metabolic purposes. The various transporters have different properties both with respect to their transport functions and with respect to their ability to act as ion channels. Further, they are differentially regulated. To understand the physiological roles of the individual transporter subtypes, it is necessary to obtain information on their distributions and expression levels. Quantitative data are important as the functional capacity is limited by the number of transporter molecules. The most important and most abundant transporters for removal of transmitter glutamate in the brain are EAAT2 (GLT-1) and EAAT1 (GLAST), while GAT1 and GAT3 are the major GABA transporters in the brain. EAAT3 (EAAC1) does not appear to play a role in signal transduction, but plays other roles. Due to their high uncoupled anion conductance, EAAT4 and EAAT5 seem to be acting more like inhibitory glutamate receptors than as glutamate transporters. GAT2 and BGT1 are primarily expressed in the liver and kidney, but are also found in the leptomeninges, while the levels in brain tissue proper are too low to have any impact on GABA removal, at least in normal young adult mice. The present review will provide summary of what is currently known and will also discuss some methodological pitfalls.

Keywords: GABA uptake, glutamate uptake, BGT1, GAT1, GAT3, GAT2, EAAT2, EAAT1

\section{GLUTAMATE AND GABA AS NEUROTRANSMITTERS}

Gamma-aminobutyric acid (GABA) and glutamate are, respectively, the major inhibitory and the major excitatory neurotransmitters in the mammalian central nervous system (1-3), and are thereby involved directly or indirectly in most aspects of normal brain function including cognition, memory, and learning. They are exocytosed from nerve terminals, and it is currently debated whether they are also exocytosed from astrocytes [e.g., Ref. (4$6)]$. When interpreting data in the literature, it is important to keep in mind that astrocytic preparations differ greatly depending on the source of the cells and the culturing conditions, and cultured astrocytes may differ substantially from mature brain astrocytes (5).

\section{THE IMPORTANCE OF CELLULAR UPTAKE OF GABA AND GLUTAMATE}

Both GABA and glutamate exert their signaling roles by acting on receptors located on the surface of the cells expressing them [e.g., Ref. (7-13)]. Therefore it is the transmitter concentration in the surrounding extracellular fluid that determines the extent of receptor stimulation. It is of critical importance that the extracellular

Abbreviations: BGT1, betaine-GABA transporter (slc6a12); DTT, dithiothreitol; EAAC1, excitatory amino acid carrier (EAAT3; slcla1); EAAT, excitatory amino acid transporter; GAT1, GABA transporter 1 (slc6a1); GAT2, GABA transporter 2 (slc6a13); GAT3, GABA transporter 3 (slc6a11); GABA, gamma-aminobutyric acid; GLAST, glutamate-aspartate transporter (EAAT1; slcla3); GLT-1, glutamate transporter 2 (EAAT2; slc1a2). concentrations are kept low [e.g., Ref. $(3,14-16)]$. This is required for a high signal to noise (background) ratio in synaptic as well as in extrasynaptic transmission.

Low extracellular levels can only be maintained by cellular uptake because there is no extracellular metabolism of GABA and glutamate [e.g., Ref. (17-24)].

For glutamate, there is another reason to keep the extracellular levels low. Excessive activation of glutamate receptors is harmful, and glutamate is thereby toxic in high concentrations [for review and references, see Ref. (3)].

\section{EARLY CHARACTERIZATION OF GABA AND GLUTAMATE UPTAKE}

It was soon realized that the mechanisms responsible for the uptake of GABA and glutamate are independent of each other $(21,25,26)$ and that there is heterogeneity both within GABA uptake (27) and glutamate uptake (28-33). Uptake activity of both GABA and glutamate uptake was found to be present both in glial cells and in neurons [for review, see Ref. $(1,24,34)]$. The uptake processes are electrogenic and in the case of glutamate uptake it is driven by the ion gradients of $\mathrm{K}^{+}$and $\mathrm{Na}^{+}$[for review, see Ref. (35)] while the uptake of GABA is driven by the gradients of $\mathrm{Na}^{+}$and $\mathrm{Cl}^{-}$(35-39). The dependency of the transport process on the electrochemical gradients across the plasma membranes further implies that the uptake can reverse if the gradients are sufficiently weakened. In fact, during cerebral ischemia massive amounts of glutamate are released (40) and transporter reversal may be one 
of the mechanisms [e.g., Ref. (41-45)] albeit not the only one (3). Further, the transporters can operate as exchangers. The latter phenomenon complicated early attempts to study binding of glutamate to the uptake sites in membrane preparations (46-48), and it took some time before it was realized that transportable uptake inhibitors induce release of internal endogenous substrates by enabling heteroexchange [e.g., Ref. $(3,49)]$.

\section{IDENTIFICATION OF GABA AND GLUTAMATE TRANSPORTERS}

The first neurotransmitter transporter to be molecularly identified was the GABA transporter (Table 1) now known as GAT1 (slc6a1). This was accomplished by purifying the protein in active form using reconstitution of transport activity as the assay to monitor the purification process (50). Based on peptide sequences derived from the pure protein, probes were synthesized and cDNA was successfully isolated from a rat brain library (51). This turned out to be the first member of a new family of transporters. Another three GABA transporters (GAT2, slc6a13; GAT3, slc6a11; BGT1, slc6a12) were subsequently identified $(52,53)$. The first cloning of BGT1 resulted from screening of a Madin-Darby canine kidney (MDCK) cell cDNA library for expression of a betaine transporter in Xenopus oocytes (54). BGT1 homologs were subsequently cloned from mouse brain (53), and from human brain (55) and kidney (56). In fact, the mammalian genome contains about 20 transporters with structural similarities to GAT1 $(37,38,57)$. Interestingly, none of these were glutamate transporters.

The first glutamate transporter (Table 2) to be isolated in active form (58) and localized $(59,60)$ was the one now known as EAAT2 [GLT-1; slc1a2; Ref. (61)]. Simultaneously, but independently of each other, three other research teams succeeded in cloning another two glutamate transporters using completely different approaches (62-64). The three human counterparts were quickly identified and named Excitatory Amino Acid Transporter (EAAT) 1-3 (65). Another two glutamate transporters were found later: EAAT4 (66) and EAAT5 (67). All the EAATs catalyze $\mathrm{Na}^{+}$and $\mathrm{K}^{+}$-coupled transport of $\mathrm{L}$-glutamate as well as $\mathrm{L}$ - and $\mathrm{D}^{-}$ aspartate, but not D-glutamate. Further, down-regulation of glial glutamate transporters after glutamatergic denervation suggested complex regulation (68). Glutamate transporter expression turned out to be regulated via several different pathways and neurons were found to influence astroglial expression levels [e.g., Ref. (69-72)]. In fact, there is regulation on apparently all levels from transcription to posttranslational modification and trafficking $(73,74)$. This degree of complexity suggested that the transporters might have more roles than simply representing drainage and re-cycling systems [for review, see Ref. (3, 73, 75-79)]. Pharmacological manipulation of transporter expression or function would be highly interesting from a therapeutic point of view (80). A spider toxin has been found to enhance EAAT2 transport activity (81), but the compound responsible has not yet been identified. Recently, it was discovered EAAT2 expression can be increased by $\beta$-lactam antibiotics $(82,83)$, and that finding has got considerable attention.

\section{FUNCTIONAL PROPERTIES OF GABA TRANSPORTERS}

The molecular functioning of GAT1 has been extensively studied (84-92), but there are also data on the other three GABA
Table 1 | Overview of the nomenclature of plasma membrane GABA transporters.

Name adopted by HUGO Other names
(www.genenames.org)

GABA transporter 1 (GAT1;

Rat GAT1, human GAT1, mouse GAT1

slc6a1)

$$
(51,52)
$$

GABA transporter 2 (GAT2; slc6a13)

Rat GAT2, human GAT2, mouse GAT3 $(52,277)$

GABA transporter 3 (GAT3;

slc6a11)

Betaine-GABA transporter

(BGT1; slc6a12)

Rat GAT3, hGAT-3, mGAT4, GAT-B (52, $277,278)$

Rat BGT1, rat GAT-4, rat NTBE, human GAT-4, mouse GAT2 $(52-56,180)$

Taurine transporter (TAUT; slc6a6) (279), (280)

Proton-coupled amino acid transporter 1 (PAT1; slc36a1)

Imino acid carrier, LYAAT-1, tramdorin 3 (281)

The neurotransmitter transporter family (SLC6) comprises four GABA transporters as well as the taurine transporter (280). Both the taurine transporter and the proton-coupled amino acid transporter 1 (282) are able to transport GABA, but with low affinity $\left(K_{m}>1 \mathrm{mM}\right)$ and are therefore usually not classified as "GABA transporters." The nomenclature used here is the one adopted by the HUGO Gene Nomenclature Committee (283).

Table 2 | Overview of the nomenclature of plasma membrane glutamate transporters.

\begin{tabular}{ll}
\hline HUGO name & Other names \\
\hline Excitatory amino acid transporter 1 (EAAT1; slc1a3) & GLAST $(63-65)$ \\
Excitatory amino acid transporter 2 (EAAT2; slc1a2) & GLT-1 $(61,65)$ \\
Excitatory amino acid transporter 3 (EAAT3; slc1a1) & EAAC1 $(62,65,211)$ \\
Excitatory amino acid transporter 4 (EAAT4; slc1a6) & $(66)$ \\
Excitatory amino acid transporter 5 (EAAT5; slc1a7) & (67)
\end{tabular}

Glutamate transporters do not belong to the slc6-family, but to the slc1-family (high-affinity glutamate and neutral amino acid transporter family). Although there are several proteins with ability to transport glutamate, the term "glutamate transporter" is usually used to describe the five "High-Affinity Glutamate Transporters" also called "Excitatory Amino Acid Transporters (EAATs)." The actual meanings of the acronyms (GLAST, glutamate-aspartate transporter; GLT-1, glutamate transporter; EAAC, excitatory amino acid carrier; EAAT, excitatory amino acid transporter) are not important, as they do not reflect functional differences among the transporters. The nomenclature used here is the one adopted by the HUGO Gene Nomenclature Committee (283).

transporters (93-100). GAT1 and GAT3 are coupled to both sodium and chloride. Like for the glutamate transporters (see below), there is also uncoupled transport (101-103). The affinities for GABA vary greatly. The reported $K_{\mathrm{m}}$ values for the mouse isoforms are $0.8,8,18$, and $80 \mu \mathrm{M}$, respectively, for GAT3, GAT1, GAT2, and BGT1 $(52,53,104)$. Nipecotic acid and $\beta$ guanidinopropionate inhibit the GAT1-3, but not the taurine transporter (105). GAT2 (slc6a13) transports $\beta$-alanine and also taurine with $K_{\mathrm{m}}$ of 28 and $540 \mu \mathrm{M}$, respectively $(52,106)$. Mouse BGT1 (slc6a12) transports betaine with a $K_{\mathrm{m}}$ of about $200 \mu \mathrm{M}$, 
but no significant transport of $\beta$-alanine could be detected (53). Mouse GAT2 and GAT3 are more potently inhibited by isoserine, $\beta$-alanine, and hypotaurine than GAT1 and BGT1 (107). Tiagabine is highly selective for GAT1 $(24,108,109)$. Recently, new functional assays have been developed for compound screening $(110,111)$ leading to development of several new compounds (112-116).

\section{FUNCTIONAL PROPERTIES OF GLUTAMATE TRANSPORTERS}

Most of the reported $K_{\mathrm{m}}$ values of EAAT2 for glutamate are at around $20 \mu \mathrm{M}$ and the affinities of EAAT1 and EAAT3 differ from EAAT2 with a factor of $<2(3)$, while the affinities of EAAT4 and EAAT5 are, respectively, one order of magnitude higher and lower $(3,65-67)$. Stoichiometry of the transport mediated by EAAT $1-3$ is exchange of one internal potassium ion with the following external substrates: one glutamate, three sodium ions, and one hydrogen ion (117-119). The coupling to three sodium ions makes these transporters less prone to reversal than the GABA transporters which are coupled to two sodium ions. In addition to the coupled (stoichiometric) transport, there are uncoupled fluxes. Thus, the transporters also function as chloride channels $(66,117,120$ 122). EAAT4 and EAAT5 have the largest chloride conductance, and may function more as inhibitory glutamate receptors than as transporters $(123,124)$. In addition, a general feature of sodium coupled transport appears to be transport of water $(125,126)$. Obviously, these transporters are complex molecules, and it is important to determine their exact structure. Although the mammalian transporters have not yet been crystallized, a detailed picture is emerging $(127,128)$. The mammalian EAAT2 and EAAT3 proteins are believed to be homotrimers where the subunits are non-covalently connected (129). This is supported by recent evidence including crystallization of a bacterial glutamate transporter $(130,131)$. However, crosslinking studies indicate that there may be differences between the EAAT subtypes (123). These proteins are integral membrane proteins and they depend on the lipid environment. For instance, the GABA transporters, at least GAT1, need cholesterol to be fully active (132). EAAT2 is more robust, but is influenced by fatty acids such as arachidonic acid (133-135) and oxidation $(136,137)$. Arachidonic acid elicits a substrate-gated proton current associated with the glutamate transporter EAAT4 $(138,139)$.

All the five EAATs transport L-glutamate and DL-aspartate with high affinities $(3,140)$. There are some important differences, however. One of them is that EAAT3 transports cysteine (141). Another is that EAAT2 is blocked by kainate and dihydrokainate (65). Importantly, kainate analogs block both net uptake and exchange [for the importance of this, see Figure 5 in Ref. (3)] while most other inhibitors are substrates. Recently, a pan-EAAT blocker was developed by Shimamoto and co-workers. They synthesized a series of compounds (TBOA and variants) based on aspartate (142). The only known biological effect of these compounds is to bind to EAATs with higher affinity than glutamate $(143,144)$ and they do not interact with ASCT2 (145). An EAAT1 selective inhibitor has also been developed (146).

\section{LOCALIZATION AND FUNCTION - NUMBERS MATTER}

Still, most of the data on protein distribution relies on immunohistochemistry. Unfortunately, validation of the specificity of immunochemical labeling is difficult and the literature reflects that [for detailed discussion, see Ref. (147-149)]. The most difficult part is to obtain good negative controls. When studying human samples, post-mortem proteolysis may complicate interpretation because the termini of EAAT1 and EAAT2 are rapidly proteolyzed (150-152). Post-mortem changes affect GAT3 more than GAT1 (153). It is a good idea to use additional methods, including in situ hybridization and Western blotting. For instance, Western blotting can be used to validate regional and temporal differences in labeling intensity. However, there are pitfalls here too. One of them is that non-transporter proteins may interfere with the binding of transporters to the blotting membranes causing underestimation of expression levels $(106,154)$.

The presence of a protein is one thing. But to be physiologically relevant, sufficient numbers of molecules must be present. The number of molecules needed to accomplish a given task depends on what that task is. This consideration is particularly relevant for neurotransmitter transporters as the transport process is fairly slow. The cycling time of EAAT2 and EAAT3 are about 30 glutamate molecules per second at $V_{\max }(14,155,156)$. EAAT5 is even slower and is reported to behave as a slow-gated anion channel with little glutamate transport activity being more than an order of magnitude slower than EAAT2 (157). The cycling time for the GABA transporters has not been determined, but is believed to be similar to that of EAAT2.

The TBOA glutamate uptake blocker $(143,158)$ showed that there is a rapid extracellular turnover of glutamate (159). Despite that, the resting levels of extracellular glutamate in normal brains are low, possibly as low as $25 \mathrm{nM}$ (160) which is $0.1-0.2 \%$ of the reported $K_{\mathrm{m}}$ values for glutamate uptake (see above). At this concentration $<0.1 \%$ of the glutamate transporter molecules are expected to be actively transporting. Consequently, if ambient concentrations of $25 \mathrm{nM}$ shall be maintained, then there must be so many EAAT molecules that $0.1 \%$ of them is sufficient to keep up with the release. In fact, this is what has been determined experimentally $(123,155,161,162)$. Buffering synaptically released glutamate on a submillisecond time scale is just as demanding (163).

Also the ambient GABA levels around synapses are low; probably well below $1 \mu \mathrm{M}(164-166)$ and thereby below the $K_{\mathrm{m}}$ of GAT3. The low levels mean that GABA is removed efficiently and down to a level where BGT1 (and GAT2) is much less efficient that GAT1 and GAT3. This illustrates the point that it is not interesting whether a few BGT1 molecules can be found or not, but whether there are enough of them to make a difference. Because BGT1 has lower affinity (see above) and is expressed in the brain at much lower levels than that GAT1, it cannot contribute to GABA inactivation and does not affect seizure thresholds (167).

\section{DISTRIBUTION OF GABA TRANSPORTERS}

The purified rat GAT1 protein (50) was used to generate the first antibodies to a GABA transporter and these were used to localize GAT1 in young adult rat brain tissue (168). These antibodies were probably selective for GAT1, but reactivity toward the other GATs were never tested. Nevertheless this antibody did not label cell bodies and the strongest labeling was found in GABAergic terminals. Basket cell terminals around the base of the Purkinje 


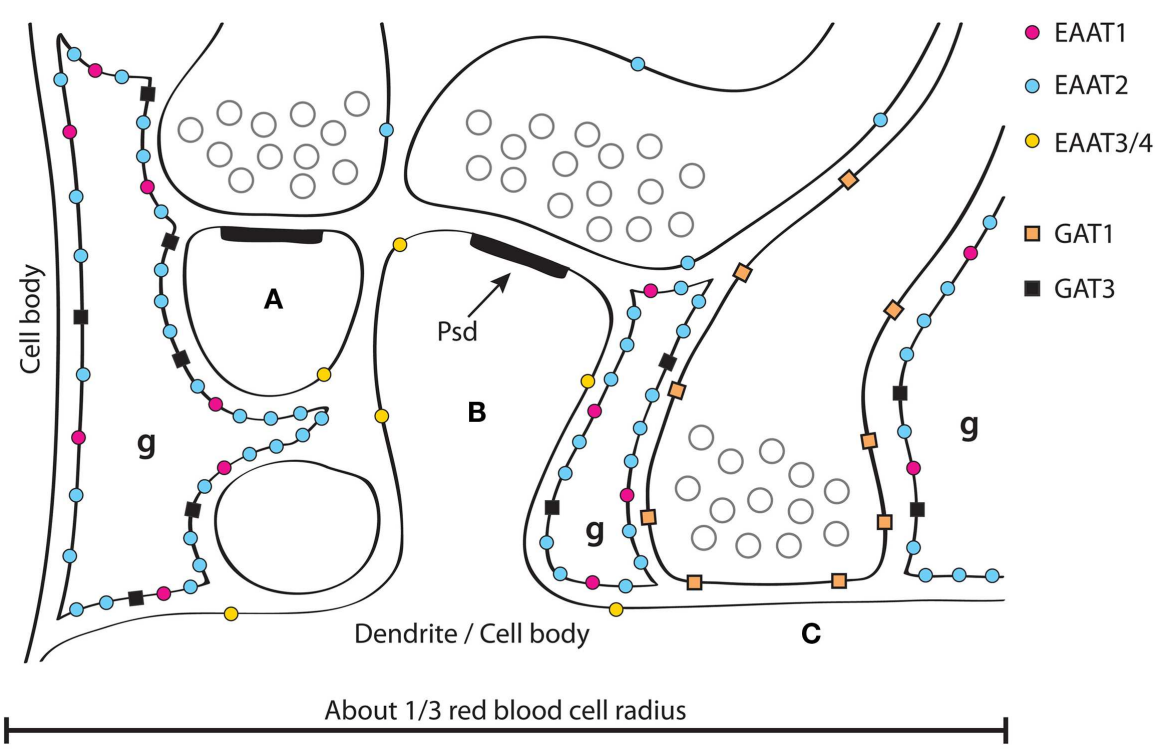

FIGURE 1 | A schematic illustration of GABA and glutamate transporter distributions around synapses in the hippocampus. Two glutamatergic synapses $(\mathbf{A}, \mathbf{B})$ are shown forming synapses asymmetric specializations with prominent post synaptic densities (PSD, one of which is labeled). GABAergic synapses (C) are often onto dendritic trunks rather than spines, and the synaptic specializations are typically symmetric. Three fine astrocyte branches are indicated $(\mathrm{g})$. Note that the synapses in the hippocampus are usually not surrounded by astrocytes, but rather contacted by an astrocyte (like a finger pointing to it, and typically from the postsynaptic side). Also note that there are no astrocytes between synapse $(\mathbf{A}, \mathbf{B})$. About $1 / 3$ of neighboring synapses in the hippocampus have no astrocytes between them in contrast to the molecular layer of the cerebellum where most synapses onto spines are typically completely surrounded by astrocytes (Figure 2) and thereby isolated from their neighbors $(162,275)$. Glutamate and GABA transporters are indicated. EAAT1 $(184,185)$ and GAT3 $(153,172,175-177)$ are selective for astrocytes, while EAAT2 is predominantly expressed in astrocytes (59), but there is also some (about 10\%) in hippocampal nerve terminals (229). This has some resemblance to GAT1 as GAT1 is mostly neuronal (170-173), but with some expression in astrocytes; particularly in the thalamus (172). There is more EAAT2 than EAAT1 in the hippocampus and the other way around in the cerebellum $(162,184)$. EAAT3 is selective for neurons, but is expressed at levels two orders of magnitude lower than EAAT2 and is targeted to dendrites and cell bodies (193) (Copyright: Neurotransporter.org; Reproduced with permission). cells, for instance, were strongly labeled. Most GABAergic terminals were labeled, but with two notable exceptions: striatonigral and Purkinje cell axon terminals. There was also some labeling of astrocytes. These findings were confirmed by antibodies produced to synthetic peptides $(169,170)$ and thereby to sequences known to differ between GABA transporter subtypes (170-173). In thalamus, however, GAT1 was not found in terminals. All the immunolabeling was in astrocytes together with GAT3 (172). GAT1 is present in neuronal cell bodies for a short time during development (174). In contrast to GAT1, GAT3 (Figures 1-3) is considered to be selectively expressed in astrocytes throughout the CNS [e.g., Ref. (153, 172, 175-177)]. The highest GAT1 levels are in the cerebral cortex while the highest GAT3 levels are in the brainstem $(178,179)$.

In contrast, GAT2 and BGT1 are predominantly expressed in hepatocytes in the liver and kidney $(52,53,106,180,181)$. Within the skull (Figure 4A), GAT2 is found only in the leptomeninges and some large blood vessels $(169,181,182)$ while BGT1 (Figure 4B) is expressed in the leptomeninges $(106,178)$.

\section{DISTRIBUTION OF GLUTAMATE TRANSPORTERS}

When the first polyclonal and monoclonal antibodies were raised against the purified EAAT2 protein (58), it was immediately clear that EAAT2 is highly expressed in astrocytes in all parts of the brain and spinal cord. The highest levels were found in the hippocampus and the neocortex $(59,60)$. Soon thereafter antibodies were raised to synthetic peptides representing parts of the various subtypes. This made it easier to ensure that the antibodies were subtype specific. The conclusions on the distribution of EAAT2 were confirmed $(183,184)$, while EAAT1 was localized for the first time (184) and also this protein was found in astrocytes throughout the central nervous system (184-188). With immunogold and electron microscopy, it was shown that both EAAT1 and EAAT2 are preferentially targeted to the plasma membranes, and that plasma membranes facing neuropil have higher densities than those facing cell bodies, other astrocytes, and pia mater (189). Quantitative immunoblotting of brain tissue extracts compared with known amounts of purified glutamate transporters showed that EAAT2 protein represents about $1 \%$ of the total forebrain protein and that it is about four times more abundant than EAAT1 in the hippocampus and six times less abundant than EAAT1 in the cerebellum (162). The high expression levels are part of the reason why the first post-embedding immunogold electron micrographs of EAAT1 and EAAT2 (189) as well as EAAT4 (123) were so clear. Of course, good antibodies and good tissue preparation are key factors, but to get good immunogold images, there must also be a large number of molecules in the plane of the section.

Immunoadsorption of transport activity revealed that EAAT2 represent about $95 \%$ of the total glutamate uptake activity in young adult forebrain tissue $(59,129)$. Deletion of the EAAT2 gene 


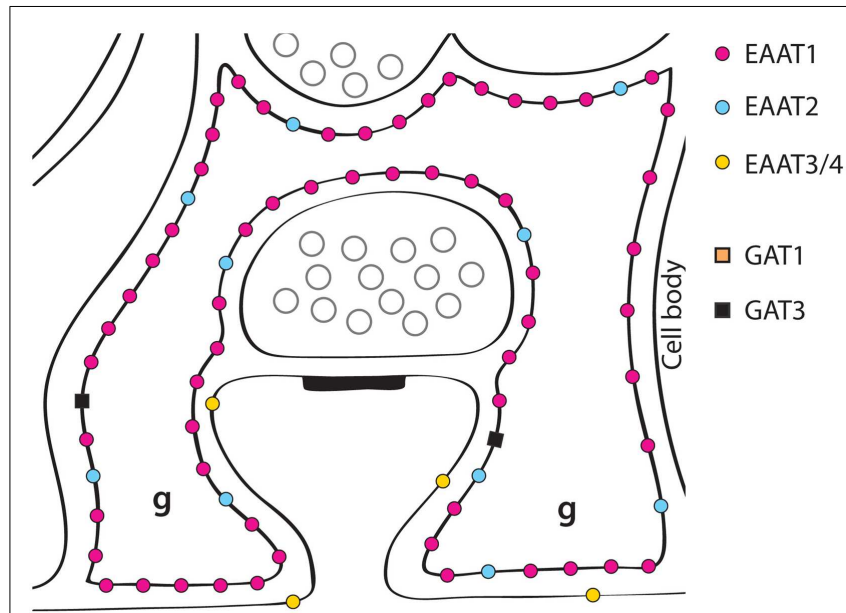

Dendrite

FIGURE 2 | A schematic illustration of glutamate transporter distributions around parallel fiber synapses on Purkinje cell spines in the molecular layer of the cerebellum. EAAT1 is expressed in the astrocytes (Bergmann glial cells) at very high levels, and about six times higher than EAAT2 $(162,184)$. Most of the EAAT4 protein is found in cerebellar Purkinje cells (the glia-covered parts of the membranes of Purkinje cell dendrites), but low levels are also found in scattered neurons in the neocortex (123). EAAT3 is also found in the Purkinje cell dendrites, as well as in the other neuron types present, but at low levels (193) (Copyright: Neurotransporter.org; Reproduced with permission).

in mice confirmed this conclusion as the glutamate uptake activity was reduced to 5\% compared to wildtype mice (190-193) without changing the expression of other glutamate transporters, glutamine synthetase (GS), and glutamate GluR1 receptors (194). Further, electrophysiological recordings of glutamate transporter currents from hippocampal astrocytes and from human embryonic kidney 293 cells expressing human EAAT2 are statistically indistinguishable suggesting that the transporter currents in astrocytes result from EAAT2 or a functionally identical isoform (155).

EAAT1 (Figures 1 and 2) is the predominant glutamate transporter in the cerebellum $(162,195)$, the inner ear $(196,197)$, the circumventricular organs (198), and in the retina [Ref. (199-204); for review, see Ref. (205)].

EAAT2 and EAAT1 are the only glutamate transporters expressed in brain astrocytes as both EAAT3 $(193,206)$ and EAAT4 $(123,207,208)$ are neuronal. Within the CNS, EAAT5 is preferentially expressed in the retina and expression in the brain is very low. It is interesting to note that also in insects (at least in the cabbage looper Trichoplusia ni) glial cells have high densities of glutamate transporters in their plasma membranes $(209,210)$.

EAAT3 is a neuronal transporter as originally suggested (62, $183,211)$ and is not expressed in glial cells $(193,206)$. It appears to be expressed in the majority if not all neurons throughout the CNS, but is selectively targeted to somata and dendrites avoiding axon terminals $(193,206)$. Within the CNS, it is found in the highest concentration in the hippocampus, but the total tissue content in young adult rat brains is about 100 times lower than that of EAAT2 (193).

EAAT4 is predominantly found in the cerebellar Purkinje cells $(66,123)$ where it is targeted to the dendrites, the spines in

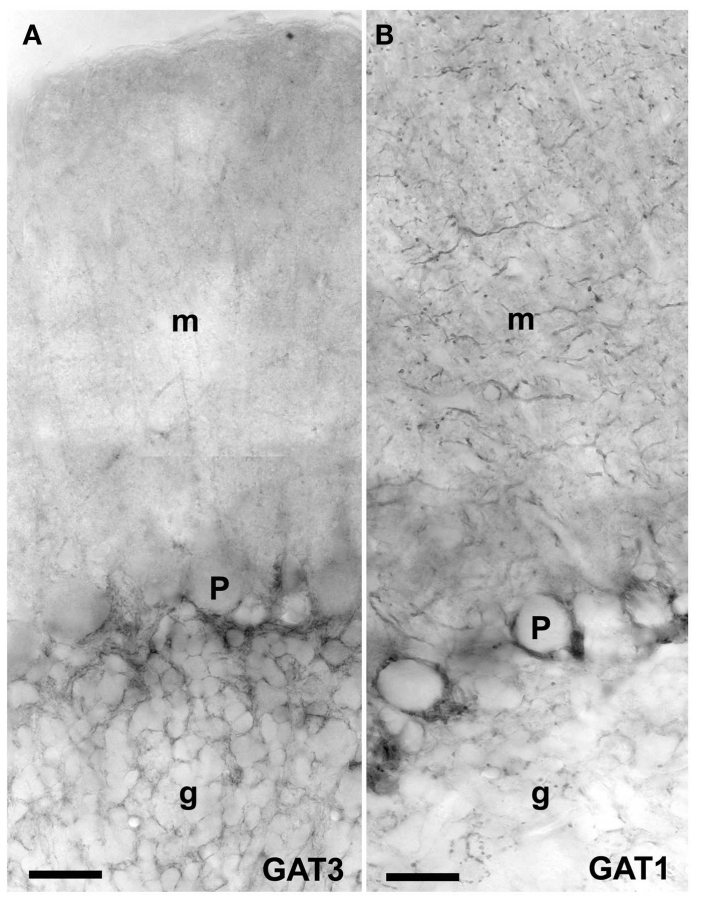

FIGURE 3 | Peroxidase labeling of GAT3 (A) and GAT1 (B) in the cerebellum [as described Ref. $(175,276)$ ]. GAT1 (slc6a1) and GAT3 (slc6a11) are the two GABA transporters that are functionally relevant for brain function, and these transporters are not expressed in the liver and kidney (181). GAT1 is mostly localized in axonal terminals in molecular layer (m) and GAT3 is in astroglial processes in granular layer (g). Note very high levels of GAT1 in basket cell terminals around the Purkinje cells (P). Scale bar: $20 \mu \mathrm{m}$ (Copyright: Neurotransporter.org; Reproduced with permission).

particular (123), but there is also some EAAT4 in a subset of forebrain neurons $(123,207,208)$.

Outside the CNS, EAAT2 is primarily expressed in glandular tissue, including mammary gland, lacrimal gland, and ducts and acini in salivary glands (212) and by perivenous hepatocytes (212, 213). It is not present in the heart (214). Thus, the main roles of EAAT2 are in the brain [for review, see Ref. $(3,15,16)$ ]. EAAT1 is found in several non-neuronal tissues (212) including, the heart, fat cells, and taste buds $(212,214,215)$, but does not appear to be important in controlling bone growth (216). EAAT3 is present in the kidney $(62,193)$. The heart expresses EAAT1, EAAT3, EAAT4, and EAAT5, but not EAAT2 (214).

\section{NEURONAL EXPRESSION OF THE EAAT2 PROTEIN}

EAAT2 mRNA is detected in astrocytes, but is also found in some neurons: pyramidal cells in CA3 hippocampus and in layer VI of the parietal neocortex (217-219). In fact, EAAT2 mRNA is reported in the majority of neurons in the neocortex and in parts of the olfactory bulb, thalamus, and inferior olive (188). That neurons have the potential to express EAAT2 protein is clear. Cultured neurons from hippocampus and cortex can express EAAT2 protein (220-222). Further, EAAT2 is transiently localized on growing axons of the mouse spinal cord before establishing astrocytic expression (223). Finally, in the normal and mature mammalian retina, EAAT2 protein is not expressed in retinal glial 


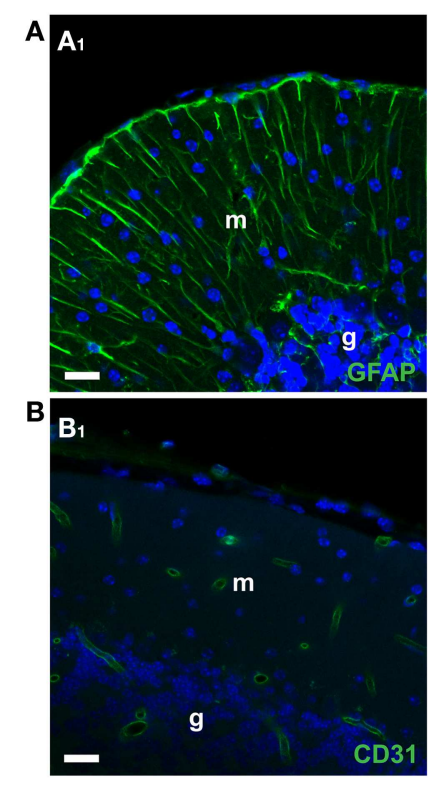

FIGURE 4 | Confocal imaging of GAT2 and BGT1 protein in the cerebellum [as described Ref. $(106,181)$ ]. (A1-A3) Show double labeling for GAT2 (red) and the astroglial marker GFAP (green). (B1-B3) Show double labeling for BGT1 (red) and the endothelial marker CD31 (green). The nuclei were visualized in blue by DAPI. Note that both GAT2 and BGT1 are found at the leptomeninges external to glia limitans. Also
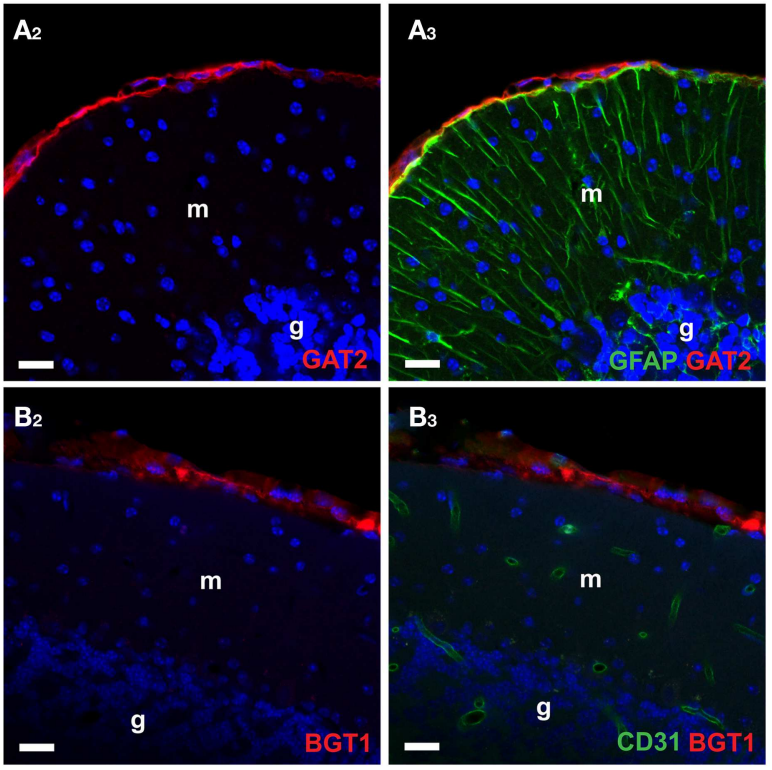

cells (neither in the Müller cells nor the astrocytes), but is exclusively expressed in neurons (cone photoreceptors and bipolar cells) (201, 205, 224-226).

Nevertheless, this was controversial for a long time and remains to be fully resolved. What is clear is that there is a significant glutamate uptake into glutamatergic nerve terminals, at least in the hippocampus CA1 [Ref. (227) for a review, see section 4.2 in Ref. (3)]. Glutamatergic axon terminals in hippocampus CA1 express EAAT2 protein, albeit at low levels (154, 228-231) and this transporter is responsible for the glutamate uptake activity in hippocampal terminals because it is absent in EAAT2 knockout mice and is sensitive to inhibition by dihydrokainate $(193,229)$. Because these terminals originate from the CA3 pyramidal cells, it makes sense that these cells have high levels of EAAT2 mRNA. This is further confirmed by the recent observation from EAAT2 eGFP BAC reporter mice (232). There is now consensus up to here, but at least two questions remain:

(a) Is nerve terminal glutamate uptake functionally relevant? Why was about half of all $\mathrm{D}$-aspartate taken up by hippocampus slices found to in axon terminals when terminals only contain around $10 \%$ of the EAAT2 protein (229)? This uptake cannot simply be disregarded as an in vitro artifact due to a higher rate of heteroexchange than net uptake (233). Preliminary data from selective deletion of EAAT2 in axon terminals indicate disturbances in synaptic transmission (234), and thereby may suggest that EAAT2 in terminals is functionally relevant.

(b) Do CA3 pyramidal neurons represent special cases or is most of the so called synaptosomal uptake measured in other brain regions also due to nerve terminal EAAT2? note that there is no co-localization of GAT2 with GFAP, and no co-localization of BGT1 with endothelial marker. In fact, BGT1 $(106,167)$ and GAT2 (181) are hardly expressed in the brain at all, but are highly expressed in the liver and kidney. Abbreviations: m, molecular layer; g, granular layer. Scale bar: $20 \mu \mathrm{m}$ (Copyright: Neurotransporter.org; Reproduced with permission).

Data obtained with EAAT2 eGFP BAC reporter mice (232) tend to favor a "yes" to this question, while in situ hybridization data argue for a "no" [e.g., Ref. $(154,235)]$.

\section{LESSONS FROM GABA TRANSPORTER KNOCKOUTS}

GAT1-deficient mice were generated as an intermediate in the construction of the mGAT1-GFP strain (236). As GAT1 is the major GABA transporter, one might expect that deletion would lead to increased extracellular GABA levels and inhibition. Reduced aggression (237), hypoalgesia (238), reduced anxiety, and depression-like behaviors (239) and altered behavioral responses to ethanol (240) may be largely as expected. However, things are more complicated. One complicating factor is that the brain still expresses GAT3 in astrocytes. Another point is that GAT1 is mostly in terminals where it recycles GABA, and GAT1 deletion leads to decreased quantal GABA release, and a differential tonic activation of GABA(A) versus GABA(B) receptors in the hippocampus (241), as well as to tremor, ataxia, nervousness, and increased GABA-induced tonic conductance in cerebellum (242). This phenotype resembles adverse effects of tiagabine treatment. Tiagabine is highly selective for GAT1 (115). It has effects on seizure control and behavior, but side effects are fatigue, dizziness, psychomotor slowing, ataxia, gastrointestinal upset, weight change, and insomnia (243). In human populations there is genetic variation within the GAT1 gene (slc6a1) and these may be associated with anxiety disorders with panic symptoms (244).

Deletion of BGT1 in mice does not affect seizure thresholds (corneal kindling; minimal clonic and tonic extension threshold test; $6 \mathrm{~Hz}$ seizure threshold test; pentamethylenetetrazole-induced seizure) of adult mice (167) in agreement with the fact that it is 
predominantly expressed in the liver and at lower levels in the kidneys and at the brain surface (106). Deletion of GAT2 in mice leads to changes in liver and brain taurine contents (181), but also does not appear to give any symptoms from the nervous system under non-challenging rearing conditions (181). Obviously, it would be interesting to study the consequences of the deletion of GAT3. These studies are under way as GAT3 knockout mice have been made by Yun Zhou, C. Guo, and Niels Christian Danbolt.

\section{LESSONS FROM GLUTAMATE TRANSPORTER KNOCKOUTS}

The possibility of connections between malfunctioning glutamate transporters and disease has got considerable attention [e.g., for review, see Ref. $(3,74,245,246)]$. Observations of the EAAT2 knockout mice illustrate why $(190,191)$. Deletion of the EAAT2 gene causes, in agreement with biochemical data $(59,129)$, a reduction in glutamate uptake activity by about 95\% (155, 190, 192, $193)$ and increased extracellular glutamate levels $(247,248)$. This has dramatic consequences as they grow up. Mice deficient in EAAT2 are not conspicuous at birth, but at 3 weeks of age they can readily be identified because they are hyperactive, epileptic, and smaller than their wildtype littermates. About half of the mice die from spontaneous seizures before they reach 4 weeks of age (190). The gradual increase in severity parallels the postnatal increase in EAAT2 expression in wildtype animals $(249,250)$, and in production of transmitter glutamate via the glutamate-glutamine cycle [reviewed by Ref. (251)]. The heterozygote EAAT2 knockout mice $( \pm)$ exhibit a 59\% decrease in EAAT2 protein levels in the brain, but do not show any apparent morphological brain abnormalities and have a similar life-span as their wildtype littermates (192). There are only moderate behavioral alterations (mild sensorimotor impairment, hyperlocomotion lower anxiety, better learning of cue-based fear conditioning), but worse context-based fear conditioning (192). However, the histological outcomes following traumatic spinal cord injury is worse in agreement with the notion that they are less protected (252). No humans have been identified at being EAAT2 deficient, but there are some reports on mutations. One patient with amyotrophic lateral sclerosis was found to harbor a mutated EAAT2 $(253,254)$ and associations of mutations with alcoholism (255), schizophrenia (256), smoking behavior (257), essential tremor (258), and bipolar disorder (259) have been reported, but it is too early to make firm conclusions.

Mice lacking EAAT1 (260) develop normally, but show symptoms of insufficient glutamate uptake in regions where EAAT1 is the major glutamate transporter. Thus, cerebellar function is affected resulting in reduced motor coordination and increased susceptibility to cerebellar injury (260), disturbance of the inner ear with exacerbation of noise-induced hearing loss (261) and disturbed retinal function (262). The EAAT1 knockout mice also display poor nesting behavior; abnormal sociability, reduced alcohol intake, and reward (260, 263-265). Lack of GLAST does not lead to spontaneous seizures like those seen in connection with EAAT2-deficiency, but when seizures are initiated, then lack of GLAST increases seizure duration and severity (266). In humans, mutations in EAAT1 are associated with episodic ataxia (246, 267, 268).

Mice lacking EAAT3 (269) develop dicarboxylic aminoaciduria, and possibly a somewhat reduced spontaneous locomotor activity (open field). They do not show signs of neurodegeneration at young age and do not have epilepsy (269-271), but may age prematurely (270). Humans lacking EAAT3 develop dicarboxylic aminoaciduria as expected from the mice data (272). Further, human EAAT3 polymorphisms have been reported to be associated with obsessive-compulsive disorders $(273,274)$.

\section{CONCLUDING REMARIS}

The various GABA and glutamate transporters have select expression patterns and distributions. The literature, however, has become confusing in part due to poorly controlled immunocytochemistry. A major reason for the latter is the reliance on the pre-absorption test which easily gives a misleading impression of specificity [for discussion, see Ref. (149)]. Post-mortem proteolysis has also contributed to confusion concerning distributions in humans (152). To sum up (for references, see above): GAT3 and EAAT1 (GLAST) are both selectively expressed in astrocytes throughout the CNS, while EAAT3 (EAAC1) and EAAT4 are selective for neurons. EAAT3 is expressed by most if not all neurons, while EAAT4 is only expressed in subpopulations. GAT1 and EAAT2 (GLT-1) are both in terminals (GABAergic and glutamatergic, respectively) and in astrocytes, but differ in that EAAT2 is predominantly in astrocytes throughout the CNS except in the retina, while GAT1 is only predominantly astrocytic at some locations (e.g., thalamus). EAAT2 is the only one of these transporters that is required for survival under non-challenging conditions. GAT2 and BGT1 are both expressed in the leptomeninges, but are not significantly expressed not around synapses (in neuropil). GAT2 is also found in some blood vessels. All these transporters are highly conserved between mammals, and they play different roles, some of which remains to be fully understood.

\section{ACKNOWLEDGMENTS}

The authors thank Gunnar Lothe for help with Figures 1 and 2. This work was supported by the Norwegian Research Council (FUGE II-183727-S10).

\section{REFERENCES}

1. Fonnum F. Glutamate: a neurotransmitter in mammalian brain. J Neurochem (1984) 42:1-11. doi:10.1111/j.1471-4159.1984.tb09689.x

2. Krnjevic K. How does a little acronym become a big transmitter? Biochem Pharmacol (2004) 68:1549-55. doi:10.1016/j.bcp.2004.06.038

3. Danbolt NC. Glutamate uptake. Prog Neurobiol (2001) 65:1-105. doi:10.1016/ S0301-0082(00)00067-8

4. Hamilton NB, Attwell D. Do astrocytes really exocytose neurotransmitters? Nat Rev Neurosci (2010) 11:227-38. doi:10.1038/nrn2803

5. Cahoy JD, Emery B, Kaushal A, Foo LC, Zamanian JL, Christopherson KS, et al. A transcriptome database for astrocytes, neurons, and oligodendrocytes: a new resource for understanding brain development and function. J Neurosci (2008) 28:264-78. doi:10.1523/JNEUROSCI.4178-07.2008

6. Li D, Herault K, Silm K, Evrard A, Wojcik S, Oheim M, et al. Lack of evidence for vesicular glutamate transporter expression in mouse astrocytes. J Neurosci (2013) 33:4434-55. doi:10.1523/JNEUROSCI.3667-12.2013

7. Conti F, Barbaresi P, Melone M, Ducati A. Neuronal and glial localization of NR1 and NR2a/b subunits of the NMDA receptor in the human cerebral cortex. Cereb Cortex (1999) 9:110-20. doi:10.1093/cercor/9.2.110

8. Bergles DE, Roberts JD, Somogyi P, Jahr CE. Glutamatergic synapses on oligodendrocyte precursor cells in the hippocampus. Nature (2000) 405:187-91. doi:10.1038/35012083

9. Moldrich RX, Chapman AG, De Sarro G, Meldrum BS. Glutamate metabotropic receptors as targets for drug therapy in epilepsy. Eur J Pharmacol (2003) 476:3-16. doi:10.1016/S0014-2999(03)02149-6 
10. Kolodziejczyk K, Saab AS, Nave K-A, Attwell D. Why do oligodendrocyte lineage cells express glutamate receptors? F1000 Biol Rep (2010) 2:57. doi:10.3410/B2-57

11. Bergles DE, Jabs R, Steinhauser C. Neuron-glia synapses in the brain. Brain Res Rev (2010) 63:130-7. doi:10.1016/j.brainresrev.2009.12.003

12. Kullmann DM, Ruiz A, Rusakov DM, Scott R, Semyanov A, Walker MC. Presynaptic, extrasynaptic and axonal GABAA receptors in the CNS: where and why? Prog Biophys Mol Biol (2005) 87:33-46. doi:10.1016/j.pbiomolbio.2004.06.003

13. Meldrum BS, Rogawski MA. Molecular targets for antiepileptic drug development. Neurotherapeutics (2007) 4:18-61. doi:10.1016/j.nurt.2006.11.010

14. Grewer C, Rauen T. Electrogenic glutamate transporters in the CNS: molecular mechanism, pre-steady-state kinetics, and their impact on synaptic signaling. J Membr Biol (2005) 203:1-20. doi:10.1007/s00232-004-0731-6

15. Beart PM, O’Shea RD. Transporters for L-glutamate: an update on their molecular pharmacology and pathological involvement. Br J Pharmacol (2007) 150:5-17. doi:10.1038/sj.bjp.0706949

16. Tzingounis AV, Wadiche JI. Glutamate transporters: confining runaway excitation by shaping synaptic transmission. Nat Rev Neurosci (2007) 8:935-47. doi:10.1038/nrn2274

17. Iversen LL, Neal MJ. The uptake of [3H] GABA by slices of rat cerebral cortex. J Neurochem (1968) 15:1141-9. doi:10.1111/j.1471-4159.1968.tb06831.x

18. Kuriyama K, Weinstein H, Roberts E. Uptake of gamma-aminobutyric acid by mitochondrial and synaptosomal fractions from mouse brain. Brain Res (1969) 16:479-92. doi:10.1016/0006-8993(69)90240-6

19. Neal MJ, Iversen LL. Subcellular distribution of endogenous and $(3 \mathrm{H})$ gammaaminobutyric acid in rat cerebral cortex. J Neurochem (1969) 16:1245-52. doi:10.1111/j.1471-4159.1969.tb05972.x

20. Iversen LL, Johnston GA. GABA uptake in rat central nervous system: comparison of uptake in slices and homogenates and the effects of some inhibitors. J Neurochem (1971) 18:1939-50. doi:10.1111/j.1471-4159.1971.tb09600.x

21. Logan WJ, Snyder SH. Unique high affinity uptake systems for glycine, glutamic and aspartic acids in central nervous tissue of the rat. Nature (1971) 234:297-9. doi:10.1038/234297b0

22. Iversen LL, Kelly JS. Uptake and metabolism of gamma-aminobutyric acid by neurones and glial cells. Biochem Pharmacol (1975) 24:933-8. doi:10.1016/ 0006-2952(75)90422-0

23. Johnston GA. Glutamate uptake and its possible role in neurotransmitter inactivation. In: Roberts PJ, Storm-Mathisen J, Johnston GA, editors. Glutamate: Transmitter in the Central Nervous System. Chichester: John Wiley \& Sons (1981). p. 77-87.

24. Borden LA. GABA transporter heterogeneity: pharmacology and cellular localization. Neurochem Int (1996) 29:335-56. doi:10.1016/0197-0186(95)00158-1

25. Logan WJ, Snyder SH. High affinity uptake systems for glycine, glutamic and aspartic acids in synaptosomes of rat central nervous tissues. Brain Res (1972) 42:413-31. doi:10.1016/0006-8993(72)90540-9

26. Balcar VJ, Johnston GA. The structural specificity of the high affinity uptake of L-glutamate and L-aspartate by rat brain slices. J Neurochem (1972) 19:2657-66. doi:10.1111/j.1471-4159.1972.tb01325.x

27. Kanner BI, Bendahan A. Two pharmacologically distinct sodium- and chloridecoupled high-affinity gamma-aminobutyric acid transporters are present in plasma membrane vesicles and reconstituted preparations from rat brain. Proc Natl Acad Sci U S A (1990) 87:2550-4. doi:10.1073/pnas.87.7.2550

28. Ferkany J, Coyle JT. Heterogeneity of sodium-dependent excitatory amino acid uptake mechanisms in rat brain. J Neurosci Res (1986) 16:491-503. doi:10.1002/jnr.490160305

29. Robinson MB, Hunter-Ensor M, Sinor J. Pharmacologically distinct sodiumdependent L- $\left[{ }^{3} \mathrm{H}\right]$ glutamate transport processes in rat brain. Brain Res (1991) 544:196-202. doi:10.1016/0006-8993(91)90054-Y

30. Robinson MB, Sinor JD, Dowd LA, Kerwin JF. Subtypes of sodium-dependent high-affinity L- $\left[{ }^{3} \mathrm{H}\right]$ glutamate transport activity - pharmacologic specificity and regulation by sodium and potassium. J Neurochem (1993) 60:167-79. doi:10.1111/j.1471-4159.1993.tb05835.x

31. Fletcher EJ, Johnston GA. Regional heterogeneity of L-glutamate and Laspartate high-affinity uptake systems in the rat CNS. J Neurochem (1991) 57:911-4. doi:10.1111/j.1471-4159.1991.tb08237.x

32. Balcar VJ, Li Y. Heterogeneity of high affinity uptake of L-glutamate and Laspartate in the mammalian central nervous system. Life Sci (1992) 51:1467-78. doi:10.1016/0024-3205(92)90556-5
33. Rauen T, Jeserich G, Danbolt NC, Kanner BI. Comparative analysis of sodiumdependent L-glutamate transport of synaptosomal and astroglial membrane vesicles from mouse cortex. FEBS Lett (1992) 312:15-20. doi:10.1016/00145793(92)81401-7

34. Schousboe A. Transport and metabolism of glutamate and GABA in neurons and glial cells. Int Rev Neurobiol (1981) 22:1-45. doi:10.1016/S0074-7742(08) 60289-5

35. Kanner BI, Schuldiner S. Mechanism of transport and storage of neurotransmitters. CRC Crit Rev Biochem (1987) 22:1-38. doi:10.3109/ 10409238709082546

36. Koyama Y, Baba A, Iwata H. L-[35S]cysteic acid selectively detects chloridedependent L-glutamate transporters in synaptic membrane. Brain Res (1989) 487:113-9. doi:10.1016/0006-8993(89)90946-3

37. Kanner BI. Structure and function of sodium-coupled GABA and glutamate transporters. J Membr Biol (2006) 213:89-100. doi:10.1007/s00232006-0877-5

38. Eulenburg V, Gomeza J. Neurotransmitter transporters expressed in glial cells as regulators of synapse function. Brain Res Rev (2010) 63:103-12. doi:10.1016/j.brainresrev.2010.01.003

39. Kristensen AS, Andersen J, Jorgensen TN, Sorensen L, Eriksen J, Loland CJ, et al. SLC6 neurotransmitter transporters: structure, function, and regulation. Pharmacol Rev (2011) 63:585-640. doi:10.1124/pr.108.000869

40. Benveniste H, Drejer J, Schousboe A, Diemer NH. Elevation of the extracellular concentrations of glutamate and aspartate in rat hippocampus during transient cerebral ischemia monitored by intracerebral microdialysis. J Neurochem (1984) 43:1369-74. doi:10.1111/j.1471-4159.1984.tb05396.x

41. Kauppinen RA, McMahon HT, Nicholls DG. $\mathrm{Ca}^{2+}$-dependent and $\mathrm{Ca}^{2+}$. independent glutamate release, energy status and cytosolic free $\mathrm{Ca}^{2+}$. Neuroscience (1988) 27:175-82. doi:10.1016/0306-4522(88)90228-X

42. Sánchez-Prieto J, González P. Occurrence of a large Ca2+-independent release of glutamate during anoxia in isolated nerve terminals (synaptosomes). $\mathrm{J} \mathrm{Neu}$ rochem (1988) 50:1322-4. doi:10.1111/j.1471-4159.1988.tb10611.x

43. Rossi DJ, Oshima T, Attwell D. Glutamate release in severe brain ischaemia is mainly by reversed uptake. Nature (2000) 403:316-21. doi:10. $1038 / 35002090$

44. Jabaudon D, Scanziani M, Ghwiler BH, Gerber U. Acute decrease in net glutamate uptake during energy deprivation. Proc Natl Acad Sci U S A (2000) 97:5610-5. doi:10.1073/pnas.97.10.5610

45. Phillis JW, Ren J, O’Regan MH. Transporter reversal as a mechanism of glutamate release from the ischemic rat cerebral cortex: studies with DL-threobeta-benzyloxyaspartate. Brain Res (2000) 868:105-12. doi:10.1016/S00068993(00)02303-9

46. Danbolt NC, Storm-Mathisen J. Na+-dependent "binding” of D-aspartate in brain membranes is largely due to uptake into membrane-bounded saccules. J Neurochem (1986) 47:819-24. doi:10.1111/j.1471-4159.1986.tb00684.x

47. Danbolt NC, Storm-Mathisen J. Inhibition by $\mathrm{K}+$ of $\mathrm{Na}+$-dependent $\mathrm{D}$ aspartate uptake into brain membrane saccules. J Neurochem (1986) 47:825-30. doi:10.1111/j.1471-4159.1986.tb00685.x

48. Danbolt NC. The high affinity uptake system for excitatory amino acids in the brain. Prog Neurobiol (1994) 44:377-96. doi:10.1016/0301-0082(94) 90033-7

49. Volterra A, Bezzi P, Rizzini BL, Trotti D, Ullensvang K, Danbolt NC, et al. The competitive transport inhibitor L-trans-pyrrolidine-2,4-dicarboxylate triggers excitotoxicity in rat cortical neuron-astrocyte co-cultures via glutamate release rather than uptake inhibition. Eur J Neurosci (1996) 8:2019-28. doi:10.1111/j.1460-9568.1996.tb01345.x

50. Radian R, Bendahan A, Kanner BI. Purification and identification of the functional sodium- and chloride-coupled gamma-aminobutyric acid transport glycoprotein from rat brain. J Biol Chem (1986) 261:15437-41.

51. Guastella J, Nelson N, Nelson H, Czyzyk L, Keynan S, Miedel MC, et al. Cloning and expression of a rat brain GABA transporter. Science (1990) 249:1303-6. doi:10.1126/science.1975955

52. Liu QR, López-Corcuera B, Mandiyan S, Nelson H, Nelson N. Molecular characterization of 4 pharmacologically distinct alpha-aminobutyric acid transporters in mouse brain. J Biol Chem (1993) 268:2106-12.

53. López-Corcuera B, Liu QR, Mandiyan S, Nelson H, Nelson N. Expression of a mouse brain cDNA encoding novel gamma-aminobutyric acid transporter. J Biol Chem (1992) 267:17491-3. 
54. Yamauchi A, Uchida S, Kwon HM, Preston AS, Robey RB, Garcia-Perez A, et al. Cloning of a $\mathrm{Na}^{+}$-dependent and $\mathrm{Cl}^{-}$-dependent betaine transporter that is regulated by hypertonicity. J Biol Chem (1992) 267:649-52.

55. Borden LA, Smith KE, Gustafson EL, Branchek TA, Weinshank RL. Cloning and expression of a betaine/GABA transporter from human brain. JNeurochem (1995) 64:977-84. doi:10.1046/j.1471-4159.1995.64030977.x

56. Rasola A, Galietta LJ, Barone V, Romeo G, Bagnasco S. Molecular cloning and functional characterization of a GABA betaine transporter from human kidney. FEBS Lett (1995) 373:229-33. doi:10.1016/0014-5793(95)01052-G

57. Gether U, Andersen PH, Larsson OM, Schousboe A. Neurotransmitter transporters: molecular function of important drug targets. Trends Pharmacol Sci (2006) 27:375-83. doi:10.1016/j.tips.2006.05.003

58. Danbolt NC, Pines G, Kanner BI. Purification and reconstitution of the sodium- and potassium-coupled glutamate transport glycoprotein from rat brain. Biochemistry (1990) 29:6734-40. doi:10.1021/bi00480a025

59. Danbolt NC, Storm-Mathisen J, Kanner BI. An $\left[\mathrm{Na}^{+}+\mathrm{K}^{+}\right]$coupled L-glutamate transporter purified from rat brain is located in glial cell processes. Neuroscience (1992) 51:295-310. doi:10.1016/0306-4522(92)90316- T

60. Levy LM, Lehre KP, Rolstad B, Danbolt NC. A monoclonal antibody raised against an $[\mathrm{Na}(+)+\mathrm{K}+]$ coupled L-glutamate transporter purified from rat brain confirms glial cell localization. FEBS Lett (1993) 317:79-84. doi:10.1016/ 0014-5793(93)81495-L

61. Pines G, Danbolt NC, Bjørås M, Zhang Y, Bendahan A, Eide L, et al. Cloning and expression of a rat brain L-glutamate transporter. Nature (1992) 360:464-7. doi: $10.1038 / 360464 \mathrm{a} 0$

62. Kanai Y, Hediger MA. Primary structure and functional characterization of a high-affinity glutamate transporter. Nature (1992) 360:467-71. doi:10.1038/ 360467a0

63. Storck T, Schulte S, Hofmann K, Stoffel W. Structure, expression, and functional analysis of a $\mathrm{Na}^{+}$-dependent glutamate/aspartate transporter from rat brain. Proc Natl Acad Sci U S A (1992) 89:10955-9. doi:10.1073/pnas.89.22.10955

64. Tanaka K. Expression cloning of a rat glutamate transporter. Neurosci Res (1993) 16:149-53. doi:10.1016/0168-0102(93)90082-2

65. Arriza JL, Fairman WA, Wadiche JI, Murdoch GH, Kavanaugh MP, Amara SG. Functional comparisons of three glutamate transporter subtypes cloned from human motor cortex. J Neurosci (1994) 14:5559-69.

66. Fairman WA, Vandenberg RJ, Arriza JL, Kavanaugh MP, Amara SG. An excitatory amino-acid transporter with properties of a ligand-gated chloride channel. Nature (1995) 375:599-603. doi:10.1038/375599a0

67. Arriza JL, Eliasof S, Kavanaugh MP, Amara SG. Excitatory amino acid transporter 5, a retinal glutamate transporter coupled to a chloride conductance. Proc Natl Acad Sci U S A (1997) 94:4155-60. doi:10.1073/pnas.94.8.4155

68. Levy LM, Lehre KP, Walaas SI, Storm-Mathisen J, Danbolt NC. Downregulation of glial glutamate transporters after glutamatergic denervation in the rat brain. Eur J Neurosci (1995) 7:2036-41. doi:10.1111/j.1460-9568.1995. tb00626.x

69. Gegelashvili G, Civenni G, Racagni G, Danbolt NC, Schousboe I, Schousboe A. Glutamate receptor agonists up-regulate glutamate transporter GLAST in astrocytes. Neuroreport (1996) 8:261-5. doi:10.1097/00001756-19961220000052

70. Gegelashvili G, Danbolt NC, Schousboe A. Neuronal soluble factors differentially regulate the expression of the GLT1 and GLAST glutamate transporters in cultured astroglia. J Neurochem (1997) 69:2612-5. doi:10.1046/j.1471-4159. 1997.69062612.x

71. Gegelashvili G, Dehnes Y, Danbolt NC, Schousboe A. The high-affinity glutamate transporters GLT1, GLAST and EAAT4 are regulated via different signalling mechanisms. Neurochem Int (2000) 37:163-70. doi:10.1016/S01970186(00)00019-X

72. Gegelashvili G, Robinson MB, Trotti D, Rauen T. Regulation of glutamate transporters in health and disease. Prog Brain Res (2001) 132:267-86. doi:10.1016/S0079-6123(01)32082-4

73. Robinson MB. Acute regulation of sodium-dependent glutamate transporters: a focus on constitutive and regulated trafficking. Handb Exp Pharmacol (2006) 175:251-75. doi:10.1007/3-540-29784-7_13

74. Sattler R, Rothstein JD. Regulation and dysregulation of glutamate transporters. Handb Exp Pharmacol (2006) 175:277-303. doi:10.1007/3-54029784-7_14
75. Seal RP, Amara SG. Excitatory amino acid transporters: a family in flux. Annu Rev Pharmacol Toxicol (1999) 39:431-56. doi:10.1146/annurev.pharmtox.39.1. 431

76. Bergles DE, Diamond JS, Jahr CE. Clearance of glutamate inside the synapse and beyond. Curr Opin Neurobiol (1999) 9:293-8. doi:10.1016/S0959-4388(99) 80043-9

77. Hediger MA. Glutamate transporters in kidney and brain. Am J Physiol (1999) 277:F487-92.

78. Kullmann DM. Synaptic and extrasynaptic roles of glutamate in the mammalian hippocampus. Acta Physiol Scand (1999) 166:79-83. doi:10.1046/j. 1365-201x.1999.00546.x

79. Sims KD, Robinson MB. Expression patterns and regulation of glutamate transporters in the developing and adult nervous system. Crit Rev Neurobiol (1999) 13:169-97.

80. Sheldon AL, Robinson MB. The role of glutamate transporters in neurodegenerative diseases and potential opportunities for intervention. Neurochem Int (2007) 51:333-55. doi:10.1016/j.neuint.2007.03.012

81. Fontana AC, Beleboni RO, Wojewodzic MW, Dos SWF, Coutinho-Netto J, Grutle NJ, et al. Enhancing glutamate transport: mechanism of action of Parawixin1, a neuroprotective compound from Parawixia bistriata spider venom. Mol Pharmacol (2007) 72:1228-37. doi:10.1124/mol.107.037127

82. Rothstein JD, Patel S, Regan MR, Haenggeli C, Huang YH, Bergles DE, et al. Beta-lactam antibiotics offer neuroprotection by increasing glutamate transporter expression. Nature (2005) 433:73-7. doi:10.1038/nature03180

83. Berry JD, Shefner JM, Conwit R, Schoenfeld D, Keroack M, Felsenstein D, et al. Design and initial results of a multi-phase randomized trial of ceftriaxone in amyotrophic lateral sclerosis. PLoS One (2013) 8:e61177. doi:10.1371/journal. pone.0061177

84. Kavanaugh MP, Arriza JL, North RA, Amara SG. Electrogenic uptake of gamma - aminobutyric acid by a cloned transporter expressed in Xenopus oocytes. J Biol Chem (1992) 267:22007-9.

85. Mager S, Naeve J, Quick M, Labarca C, Davidson N, Lester HA. Steady states, charge movements, and rates for a cloned GABA transporter expressed in Xenopus oocytes. Neuron (1993) 10:177-88. doi:10.1016/0896-6273(93)90309-F

86. Mager S, Kleinberger-Doron N, Keshet GI, Davidson N, Kanner BI, Lester HA. Ion binding and permeation at the GABA transporter GAT1. J Neurosci (1996) 16:5405-14.

87. Song LY, Mercado A, Vazquez N, Xie QZ, Desai R, George AL, et al. Molecular, functional, and genomic characterization of human KCC2, the neuronal K-Cl cotransporter. Brain Res Mol Brain Res (2002) 103:91-105. doi:10.1016/S0169328X(02)00190-0

88. Giovannardi S, Fesce R, Bossi E, Binda F, Peres A. Cl- affects the function of the GABA cotransporter rGAT1 but preserves the mutal relationship between transient and transport currents. Cell Mol Life Sci (2003) 60:550-6. doi: $10.1007 / \mathrm{s} 000180300046$

89. Bicho A, Grewer C. Rapid substrate-induced charge movements of the GABA transporter GAT1. Biophys J (2005) 89:211-31. doi:10.1529/biophysj.105. 061002

90. Zhou YG, Kanner BI. Transporter-associated currents in the gammaaminobutyric acid transporter GAT-1 are conditionally impaired by mutations of a conserved glycine residue. J Biol Chem (2005) 280:20316-24. doi:10.1074/jbc.M412937200

91. Omoto JJ, Maestas MJ, Rahnama-Vaghef A, Choi YE, Salto GJ, Sanchez RV, et al. Functional consequences of sulfhydryl modification of the gammaaminobutyric acid transporter 1 at a single solvent-exposed cysteine residue. J Membr Biol (2012) 245:841-57. doi:10.1007/s00232-012-9492-9

92. Ben-Yona A, Kanner BI. Functional defects in the external and internal thin gates of the gamma-aminobutyric acid (GABA) transporter GAT-1 can compensate each other. J Biol Chem (2013) 288:4549-56. doi:10.1074/jbc.M112. 430215

93. Clark JA, Amara SG. Stable expression of a neuronal gamma-aminobutyric acid transporter, GAT-3, in mammalian cells demonstrates unique pharmacological properties and ion dependence. Mol Pharmacol (1994) 46:550-7.

94. Matskevitch I, Wagner CA, Stegen C, Bröer S, Noll B, Risler T, et al. Functional characterization of the betaine/gamma-aminobutyric acid transporter BGT-1 expressed in Xenopus oocytes. J Biol Chem (1999) 274:16709-16. doi:10.1074/jbc.274.24.16709 
95. Forlani G, Bossi E, Perego C, Giovannardi S, Peres A. Three kinds of currents in the canine betaine-GABA transporter BGT-1 expressed in Xenopus laevis. Biochim Biophys Acta (2001) 1538:172-80. doi:10.1016/S0167-4889(00) 00144-0

96. Karakossian MH, Spencer SR, Gomez AQ, Padilla OR, Sacher A, Loo DD, et al. Novel properties of a mouse gamma-aminobutyric acid transporter (GAT4). J Membr Biol (2005) 203:65-82. doi:10.1007/s00232-004-0732-5

97. Wu Q, Wada M, Shimada A, Yamaynoto A, Fujita T. Functional characterization of Zn2+-sensitive GABA transporter expressed in primary cultures of astrocytes from rat cerebral cortex. Brain Res (2006) 1075:100-9. doi:10.1016/j.brainres.2005.12.109

98. Kirmse K, Kirischuk S, Grantyn R. Role of GABA transporter 3 in GABAergic synaptic transmission at striatal output neurons. Synapse (2009) 63:921-9. doi:10.1002/syn.20675

99. Nakanishi T, Fukuyama Y, Fujita M, Shirasaka Y, Tamai I. Carnitine precursor gamma-butyrobetaine is a novel substrate of the $\mathrm{Na}(+)-$ and $\mathrm{Cl}(-$ )-dependent GABA transporter Gat2. Drug Metab Pharmacokinet (2011) 26:632-6. doi:10.2133/dmpk.DMPK-11-NT-053

100. Cammack JN, Rakhilin SV, Schwartz EA. A GABA transporter operates asymmetrically and with variable stoichiometry. Neuron (1994) 13:949-60. doi:10.1016/0896-6273(94)90260-7

101. Cammack JN, Schwartz EA. Channel behavior in a gamma-aminobutyrate transporter. Proc Natl Acad Sci U S A (1996) 93:723-7. doi:10.1073/pnas.93.2. 723

102. Sonders MS, Amara SG. Channels in transporters. Curr Opin Neurobiol (1996) 6:294-302. doi:10.1016/S0959-4388(96)80111-5

103. Gerstbrein K, Sitte HH. Currents in neurotransmitter transporters. Handb Exp Pharmacol (2006) 175:95-111. doi:10.1007/3-540-29784-7_5

104. Liu QR, Mandiyan S, Nelson H, Nelson N. A family of genes encoding neurotransmitter transporters. Proc Natl Acad Sci U S A (1992) 89:6639-43. doi:10.1073/pnas.89.14.6639

105. Dominy J, Thinschmidt JS, Peris J, Dawson R, Papke RL. Taurine-induced long-lasting potentiation in the rat hippocampus shows a partial dissociation from total hippocampal taurine content and independence from activation of known taurine transporters. J Neurochem (2004) 89:1195-205. doi:10.1111/j.1471-4159.2004.02410.x

106. Zhou Y, Holmseth S, Hua R, Lehre AC, Olofsson AM, Poblete-Naredo I, et al. The betaine-GABA transporter (BGT1, slc6a12) is predominantly expressed in the liver and at lower levels in the kidneys and at the brain surface. Am J Physiol Renal Physiol (2012) 302:F316-28. doi:10.1152/ajprenal.00464. 2011

107. Kragler A, Hofner G, Wanner KT. Novel parent structures for inhibitors of the murine GABA transporters mGAT3 and mGAT4. Eur J Pharmacol (2005) 519:43-7. doi:10.1016/j.ejphar.2005.06.053

108. Nielsen EB, Suzdak PD, Andersen KE, Knutsen LJ, Sonnewald U, Braestrup C. Characterization of tiagabine (NO-328), a new potent and selective GABA uptake inhibitor. Eur J Pharmacol (1991) 196:257-66. doi:10.1016/00142999(91)90438-V

109. Krogsgaard-Larsen P, Frølund B, Frydenvang K. GABA uptake inhibitors. Design, molecular pharmacology and therapeutic aspects. Curr Pharm Des (2000) 6:1193-209. doi:10.2174/1381612003399608

110. Sindelar M, Wanner KT. Library screening by means of mass spectrometry (MS) binding assays-exemplarily demonstrated for a pseudostatic library addressing gamma-aminobutyric acid (GABA) transporter 1 (GAT1). ChemMedChem (2012) 7:1678-90. doi:10.1002/cmdc.201200201

111. Polley M, Hofner G, Wanner KT. Development and validation of an LCESI-MS/MS quantification method for a potential gamma-aminobutyric acid transporter 3 (GAT3) marker and its application in preliminary MS binding assays. Biomed Chromatogr (2013) 27:641-54. doi:10.1002/bmc.2841

112. Salat K, Wieckowska A, Wieckowski K, Hofner GC, Kaminski J, Wanner $\mathrm{KT}$, et al. Synthesis and pharmacological properties of new GABA uptake inhibitors. Pharmacol Rep (2012) 64:817-33.

113. Sindelar M, Lutz TA, Petrera M, Wanner KT. Focused pseudostatic hydrazone libraries screened by mass spectrometry binding assay: optimizing affinities toward gamma-aminobutyric acid transporter 1. J Med Chem (2013) 56:1323-40. doi:10.1021/jm301800j

114. Sitka I, Allmendinger L, Fulep G, Hofner G, Wanner KT. Synthesis of Nsubstituted acyclic beta-amino acids and their investigation as GABA uptake inhibitors. Eur J Med Chem (2013) 65C:487-99. doi:10.1016/j.ejmech.2013.04. 063

115. Quandt G, Hofner G, Wanner KT. Synthesis and evaluation of N-substituted nipecotic acid derivatives with an unsymmetrical bis-aromatic residue attached to a vinyl ether spacer as potential GABA uptake inhibitors. Bioorg Med Chem (2013) 21:3363-78. doi:10.1016/j.bmc.2013.02.056

116. Kowalczyk P, Salat K, Hofner GC, Guzior N, Filipek B, Wanner KT, et al. 2-Substituted 4-hydroxybutanamides as potential inhibitors of gammaaminobutyric acid transporters mGAT1-mGAT4: synthesis and biological evaluation. Bioorg Med Chem (2013) 21:5154-67. doi:10.1016/j.bmc.2013.06.038

117. Zerangue N, Kavanaugh MP. Flux coupling in a neuronal glutamate transporter. Nature (1996) 383:634-7. doi:10.1038/383634a0

118. Levy LM, Warr O, Attwell D. Stoichiometry of the glial glutamate transporter GLT-1 expressed inducibly in a Chinese hamster ovary cell line selected for low endogenous $\mathrm{Na}+$-dependent glutamate uptake. J Neurosci (1998) 18:9620-8.

119. Owe SG, Marcaggi P, Attwell D. The ionic stoichiometry of the GLAST glutamate transporter in salamander retinal glia. J Physiol (2006) 577:591-9. doi:10.1113/jphysiol.2006.116830

120. Wadiche JI, Arriza JL, Amara SG, Kavanaugh MP. Kinetics of a human glutamate transporter. Neuron (1995) 14:1019-27. doi:10.1016/0896-6273(95) 90340-2

121. Wadiche JI, Amara SG, Kavanaugh MP. Ion fluxes associated with excitatory amino acid transport. Neuron (1995) 15:721-8. doi:10.1016/0896-6273(95) 90159-0

122. Ryan RM, Mindell JA. The uncoupled chloride conductance of a bacterial glutamate transporter homolog. Nat Struct Mol Biol (2007) 14:365-71. doi: $10.1038 / \mathrm{nsmb} 1230$

123. Dehnes Y, Chaudhry FA, Ullensvang K, Lehre KP, Storm-Mathisen J, Danbolt NC. The glutamate transporter EAAT4 in rat cerebellar Purkinje cells: a glutamate-gated chloride channel concentrated near the synapse in parts of the dendritic membrane facing astroglia. J Neurosci (1998) 18:3606-19.

124. Veruki ML, Morkve SH, Hartveit E. Activation of a presynaptic glutamate transporter regulates synaptic transmission through electrical signaling. Nat Neurosci (2006) 9:1388-96. doi:10.1038/nn1793

125. MacAulay N, Gether U, Klaerke DA, Zeuthen T. Water transport by the human $\mathrm{Na}^{+}$-coupled glutamate cotransporter expressed in Xenopus. J Physiol (2001) 530:367-78. doi:10.1111/j.1469-7793.2001.0367k.x

126. MacAulay N, Hamann S, Zeuthen T. Water transport in the brain: role of cotransporters. Neuroscience (2004) 129:1031-44. doi:10.1016/j.neuroscience. 2004.06.045

127. Kanner BI. Gate movements in glutamate transporters. ACS Chem Biol (2007) 2:163-6. doi:10.1021/cb700040e

128. Gouaux E. Review. The molecular logic of sodium-coupled neurotransmitter transporters. Philos Trans R Soc Lond B Biol Sci (2009) 364:149-54. doi:10.1098/rstb.2008.0181

129. Haugeto Ø, Ullensvang K, Levy LM, Chaudhry FA, Honoré T, Nielsen M, et al. Brain glutamate transporter proteins form homomultimers. JBiol Chem (1996) 271:27715-22. doi:10.1074/jbc.271.44.27715

130. Yernool D, Boudker O, Folta-Stogniew E, Gouaux E. Trimeric subunit stoichiometry of the glutamate transporters from Bacillus caldotenax and Bacillus stearothermophilus. Biochemistry (2003) 42:12981-8. doi:10.1021/ bi030161q

131. Yernool D, Boudker O, Jin Y, Gouaux E. Structure of a glutamate transporter homologue from Pyrococcus horikoshii. Nature (2004) 431:811-8. doi:10.1038/nature03018

132. Shouffani A, Kanner BI. Cholesterol is required for the reconstruction of the sodium- and chloride-coupled, gamma-aminobutyric acid transporter from rat brain. J Biol Chem (1990) 265:6002-8.

133. Barbour B, Szatkowski M, Ingledew N, Attwell D. Arachidonic acid induces a prolonged inhibition of glutamate uptake into glial cells. Nature (1989) 342:918-20. doi:10.1038/342918a0

134. Trotti D, Volterra A, Lehre KP, Rossi D, Gjesdal O, Racagni G, et al. Arachidonic acid inhibits a purified and reconstituted glutamate transporter directly from the water phase and not via the phospholipid membrane. J Biol Chem (1995) 270:9890-5. doi:10.1074/jbc.270.17.9890

135. Zerangue N, Arriza JL, Amara SG, Kavanaugh MP. Differential modulation of human glutamate transporter subtypes by arachidonic acid. J Biol Chem (1995) 270:6433-5. doi:10.1074/jbc.270.12.6433 
136. Trotti D, Rossi D, Gjesdal O, Levy LM, Racagni G, Danbolt NC, et al. Peroxynitrite inhibits glutamate transporter subtypes. J Biol Chem (1996) 271:5976-9. doi:10.1074/jbc.271.11.5976

137. Trotti D, Danbolt NC, Volterra A. Glutamate transporters are oxidantvulnerable: a molecular link between oxidative and excitotoxic neurodegeneration? Trends Pharmacol Sci (1998) 19:328-34. doi:10.1016/S0165-6147(98) 01230-9

138. Fairman WA, Sonders MS, Murdoch GH, Amara SG. Arachidonic acid elicits a substrate-gated proton current associated with the glutamate transporter EAAT4. Nat Neurosci (1998) 1:105-13. doi:10.1038/355

139. Tzingounis AV, Lin CL, Rothstein JD, Kavanaugh MP. Arachidonic acid activates a proton current in the rat glutamate transporter EAAT4. J Biol Chem (1998) 273:17315-7. doi:10.1074/jbc.273.28.17315

140. Bridges RJ, Kavanaugh MP, Chamberlin AR. A pharmacological review of competitive inhibitors and substrates of high-affinity, sodium-dependent glutamate transport in the central nervous system. Curr Pharm Des (1999) 5:363-79.

141. Zerangue N, Kavanaugh MP. Interaction of L-cysteine with a human excitatory amino acid transporter. J Physiol (1996) 493:419-23.

142. Shimamoto K. Glutamate transporter blockers for elucidation of the function of excitatory neurotransmission systems. Chem Rec (2008) 8:182-99. doi:10.1002/tcr.20145

143. Shimamoto K, Lebrun B, Yasuda-Kamatani Y, Sakaitani M, Shigeri Y, Yumoto N, et al. DL-threo-beta-benzyloxyaspartate, a potent blocker of excitatory amino acid transporters. Mol Pharmacol (1998) 53:195-201.

144. Shimamoto K, Sakai R, Takaoka K, Yumoto N, Nakajima T, Amara SG, et al. Characterization of novel L-threo-beta-benzyloxyaspartate derivatives, potent blockers of the glutamate transporters. Mol Pharmacol (2004) 65:1008-15. doi:10.1124/mol.65.4.1008

145. Grewer C, Grabsch E. New inhibitors for the neutral amino acid transporter ASCT2 reveal its Na+-dependent anion leak. J Physiol (2004) 557:747-59. doi:10.1113/jphysiol.2004.062521

146. Jensen AA, Erichsen MN, Nielsen CW, Stensbol TB, Kehler J, Bunch L. Discovery of the first selective inhibitor of excitatory amino acid transporter subtype 1. J Med Chem (2009) 52:912-5. doi:10.1021/jm8013458

147. Holmseth S, Dehnes Y, Bjørnsen LP, Boulland JL, Furness DN, Bergles D, et al. Specificity of antibodies: unexpected cross reactivity of antibodies directed against the EAAT3 (EAAC) glutamate transporter. Neuroscience (2005) 136:649-60. doi:10.1016/j.neuroscience.2005.07.022

148. Holmseth S, Lehre KP, Danbolt NC. Specificity controls for immunocytochemistry. Anat Embryol (Berl) (2006) 211:257-66. doi:10.1007/s00429-005-0077-6

149. Holmseth S, Zhou Y, Follin-Arbelet VV, Lehre KP, Bergles DE, Danbolt NC. Specificity controls for immunocytochemistry: the antigen pre-adsorption test can lead to inaccurate assessment of antibody specificity. J Histochem Cytochem (2012) 60:174-87. doi:10.1369/0022155411434828

150. Beckstrøm H, Julsrud L, Haugeto Ø, Dewar D, Graham DI, Lehre KP, et al. Interindividual differences in the levels of the glutamate transporters GLAST and GLT, but no clear correlation with Alzheimer's disease. JNeurosci Res (1999) 55:218-29. doi:10.1002/(SICI) 1097-4547(19990115)55:2<218::AID-JNR9>3. 3.CO;2-C

151. Tessler S, Danbolt NC, Faull RLM, Storm-Mathisen J, Emson PC. Expression of the glutamate transporters in human temporal lobe epilepsy. Neuroscience (1999) 88:1083-91. doi:10.1016/S0306-4522(98)00301-7

152. Li Y, Zhou Y, Danbolt NC. The rates of postmortem proteolysis of glutamate transporters differ dramatically between cells and between transporter subtypes. J Histochem Cytochem (2012) 60:811-21. doi:10.1369/ 0022155412458589

153. Melone M, Barbaresi P, Fattorini G, Conti F. Neuronal localization of the GABA transporter GAT-3 in human cerebral cortex: a procedural artifact? J Chem Neuroanat (2005) 30:45-54. doi:10.1016/j.jchemneu.2005.04.002

154. Holmseth S, Scott HA, Real K, Lehre KP, Leergaard TB, Bjaalie JG, et al. The concentrations and distributions of three C-terminal variants of the GLT1 (EAAT2; slcla2) glutamate transporter protein in rat brain tissue suggest differential regulation. Neuroscience (2009) 162:1055-71. doi:10.1016/j.neuroscience.2009. 03.048

155. Otis TS, Kavanaugh MP. Isolation of current components and partial reaction cycles in the glial glutamate transporter EAAT2. J Neurosci (2000) 20:2749-57.

156. Bergles DE, Tzingounis AV, Jahr CE. Comparison of coupled and uncoupled currents during glutamate uptake by GLT-1 transporters. J Neurosci (2002) 22:10153-62.
157. Gameiro A, Braams S, Rauen T, Grewer C. The discovery of slowness: lowcapacity transport and slow anion channel gating by the glutamate transporter EAAT5. Biophys J (2011) 100:2623-32. doi:10.1016/j.bpj.2011.04.034

158. Lebrun B, Sakaitani M, Shimamoto K, Yasuda-Kamatani Y, Nakajima T. New beta-hydroxyaspartate derivatives are competitive blockers for the bovine glutamate/aspartate transporter. J Biol Chem (1997) 272:20336-9. doi:10.1074/ jbc. 272.33 .20336

159. Jabaudon D, Shimamoto K, Yasuda-Kamatani Y, Scanziani M, Gähwiler BH, Gerber U. Inhibition of uptake unmasks rapid extracellular turnover of glutamate of nonvesicular origin. Proc Natl Acad Sci U S A (1999) 96:8733-8. doi:10.1073/pnas.96.15.8733

160. Herman MA, Jahr CE. Extracellular glutamate concentration in hippocampal slice. J Neurosci (2007) 27:9736-41. doi:10.1523/JNEUROSCI.3009-07.2007

161. Bergles DE, Jahr CE. Synaptic activation of glutamate transporters in hippocampal astrocytes. Neuron (1997) 19:1297-308. doi:10.1016/S08966273(00)80420-1

162. Lehre KP, Danbolt NC. The number of glutamate transporter subtype molecules at glutamatergic synapses: chemical and stereological quantification in young adult rat brain. J Neurosci (1998) 18:8751-7.

163. Diamond JS, Jahr CE. Transporters buffer synaptically released glutamate on a submillisecond time scale. J Neurosci (1997) 17:4672-87.

164. Westergren I, Nystrom B, Hamberger A, Johansson BB. Intracerebral dialysis and the blood-brain barrier. J Neurochem (1995) 64:229-34. doi:10.1046/j. 1471-4159.1995.64010229.x

165. Westergren I, Nystrom B, Hamberger A, Nordborg C, Johansson BB. Concentrations of amino acids in extracellular fluid after opening of the bloodbrain barrier by intracarotid infusion of protamine sulfate. JNeurochem (1994) 62:159-65. doi:10.1046/j.1471-4159.1994.62010159.x

166. Juhasz G, Kekesi KA, Nyitrai G, Dobolyi A, Krogsgaard-Larsen P, Schousboe A. Differential effects of nipecotic acid and 4,5,6,7-tetrahydroisoxazolo[4,5c]pyridin-3-ol on extracellular gamma-aminobutyrate levels in rat thalamus. Eur J Pharmacol (1997) 331:139-44. doi:10.1016/S0014-2999(97)01044-3

167. Lehre AC, Rowley NM, Zhou Y, Holmseth S, Guo C, Holen T, et al. Deletion of the betaine-GABA transporter (BGT1; slc6a12) gene does not affect seizure thresholds of adult mice. Epilepsy Res (2011) 95:70-81. doi:10.1016/j. eplepsyres.2011.02.014

168. Radian R, Ottersen OP, Storm-Mathisen J, Castel M, Kanner BI. Immunocytochemical localization of the GABA transporter in rat brain. J Neurosci (1990) 10:1319-30.

169. Ikegaki N, Saito N, Hashima M, Tanaka C. Production of specific antibodies against GABA-transporter subtypes (GAT1, GAT2, GAT3) and their application to immunocytochemistry. Brain Res Mol Brain Res (1994) 26:47-54. doi:10.1016/0169-328X(94)90072-8

170. Minelli A, Brecha NC, Karschin C, Debiasi S, Conti F. GAT-1, a high-affinity GABA plasma membrane transporter, is localized to neurons and astroglia in the cerebral cortex. J Neurosci (1995) 15:7734-46.

171. Conti F, Melone M, Debiasi S, Minelli A, Brecha NC, Ducati A. Neuronal and glial localization of GAT-1, a high-affinity gamma-aminobutyric acid plasma membrane transporter, in human cerebral cortex: with a note on its distribution in monkey cortex. J Comp Neurol (1998) 396:51-63. doi:10.1002/(SICI) 1096-9861(19980622)396:1<51::AID-CNE5>3.0.CO;2-H

172. DeBiasi S, Vitellarozuccarello L, Brecha NC. Immunoreactivity for the GABA transporter-1 and GABA transporter-3 is restricted to astrocytes in the rat thalamus, a light and electron-microscopic immunolocalization. Neuroscience (1998) 83:815-28. doi:10.1016/S0306-4522(97)00414-4

173. Ribak CE, Tong WM, Brecha NC. Astrocytic processes compensate for the apparent lack of GABA transporters in the axon terminals of cerebellar Purkinje cells. Anat Embryol (Berl) (1996) 194:379-90. doi:10.1007/BF00198540

174. Yan XX, Cariaga WA, Ribak CE. Immunoreactivity for GABA plasma membrane transporter, GAT-1, in the developing rat cerebral cortex: transient presence in the somata of neocortical and hippocampal neurons. Brain Res Dev Brain Res (1997) 99:1-19. doi:10.1016/S0165-3806(96)00192-7

175. Itouji A, Sakai N, Tanaka C, Saito N. Neuronal and glial localization of two GABA transporters (GAT1 and GAT3) in the rat cerebellum. Brain Res Mol Brain Res (1996) 37:309-16. doi:10.1016/0169-328X(95)00342-P

176. Ribak CE, Tong WM, Brecha NC. GABA plasma membrane transporters, GAT-1 and GAT-3, display different distributions in the rat hippocampus. J Comp Neurol (1996) 367:595-606. doi:10.1002/(SICI)1096-9861(19960415) 367:4<595:AID-CNE9>3.0.CO;2-\# 
177. Minelli A, Debiasi S, Brecha NC, Zuccarello LV, Conti F. GAT-3, a high-affinity GABA plasma membrane transporter, is localized to astrocytic processes, and it is not confined to the vicinity of GABAergic synapses in the cerebral cortex. J Neurosci (1996) 16:6255-64.

178. Evans JE, Frostholm A, Rotter A. Embryonic and postnatal expression of four gamma-aminobutyric acid transporter mRNAs in the mouse brain and leptomeninges. J Comp Neurol (1996) 376:431-46. doi:10.1002/(SICI)10969861(19961216)376:3<431:AID-CNE6>3.0.CO;2-3

179. Conti F, Minelli A, Melone M. GABA transporters in the mammalian cerebral cortex: localization, development and pathological implications. Brain Res Brain Res Rev (2004) 45:196-212. doi:10.1016/j.brainresrev.2004.03.003

180. Burnham CE, Buerk B, Schmidt C, Bucuvalas JC. A liver-specific isoform of the betaine/GABA transporter in the rat: $\mathrm{CDNA}$ sequence and organ distribution. Biochim Biophys Acta (1996) 1284:4-8. doi:10.1016/0005-2736(96)00118-6

181. Zhou Y, Holmseth S, Guo C, Hassel B, Hofner G, Huitfeldt HS, et al. Deletion of the gamma-aminobutyric acid transporter 2 (GAT2 and SLC6A13) gene in mice leads to changes in liver and brain taurine contents. J Biol Chem (2012) 287:35733-46. doi:10.1074/jbc.M112.368175

182. Durkin MM, Smith KE, Borden LA, Weinshank RL, Branchek TA, Gustafson EL. Localization of messenger RNAs encoding three GABA transporters in rat brain: an in situ hybridization study. Brain Res Mol Brain Res (1995) 33:7-21. doi:10.1016/0169-328X(95)00101-W

183. Rothstein JD, Martin L, Levey AI, Dykes-Hoberg M, Jin L, Wu D, et al. Localization of neuronal and glial glutamate transporters. Neuron (1994) 13:713-25. doi:10.1016/0896-6273(94)90038-8

184. Lehre KP, Levy LM, Ottersen OP, Storm-Mathisen J, Danbolt NC. Differential expression of two glial glutamate transporters in the rat brain: quantitative and immunocytochemical observations. J Neurosci (1995) 15:1835-53.

185. Ginsberg SD, Martin LJ, Rothstein JD. Regional deafferentation down-regulates subtypes of glutamate transporter proteins. J Neurochem (1995) 65:2800-3. doi:10.1046/j.1471-4159.1995.65062800.x

186. Rothstein JD, Van Kammen M, Levey AI, Martin LJ, Kuncl RW. Selective loss of glial glutamate transporter GLT-1 in amyotrophic lateral sclerosis. Ann Neurol (1995) 38:73-84. doi:10.1002/ana.410380114

187. Schmitt A, Asan E, Puschel B, Kugler P. Cellular and regional distribution of the glutamate transporter GLAST in the CNS of rats: nonradioactive in situ hybridization and comparative immunocytochemistry. J Neurosci (1997) 17:1-10.

188. Berger UV, Hediger MA. Comparative analysis of glutamate transporter expression in rat brain using differential double in situ hybridization. Anat Embryol (Berl) (1998) 198:13-30. doi:10.1007/s004290050161

189. Chaudhry FA, Lehre KP, Campagne MV, Ottersen OP, Danbolt NC, StormMathisen J. Glutamate transporters in glial plasma membranes: highly differentiated localizations revealed by quantitative ultrastructural immunocytochemistry. Neuron (1995) 15:711-20. doi:10.1016/0896-6273(95)90158-2

190. Tanaka K, Watase K, Manabe T, Yamada K, Watanabe M, Takahashi K, et al. Epilepsy and exacerbation of brain injury in mice lacking the glutamate transporter GLT-1. Science (1997) 276:1699-702. doi:10.1126/science.276.5319. 1699

191. Matsugami TR, Tanemura K, Mieda M, Nakatomi R, Yamada K, Kondo T, et al. Indispensability of the glutamate transporters GLAST and GLT1 to brain development. Proc Natl Acad Sci U S A (2006) 103:12161-6. doi:10.1073/pnas. 0509144103

192. Kiryk A, Aida T, Tanaka K, Banerjee P, Wilczynski GM, Meyza K, et al. Behavioral characterization of GLT1 $( \pm)$ mice as a model of mild glutamatergic hyperfunction. Neurotox Res (2008) 13:19-30. doi:10.1007/BF03033364

193. Holmseth S, Dehnes Y, Huang YH, Follin-Arbelet VV, Grutle NJ, Mylonakou MN, et al. The density of EAAC1 (EAAT3) glutamate transporters expressed by neurons in the mammalian CNS. J Neurosci (2012) 32:6000-13. doi:10.1523/JNEUROSCI.5347-11.2012

194. Voutsinos-Porche B, Bonvento G, Tanaka K, Steiner P, Welker E, Chatton JY, et al. Glial glutamate transporters mediate a functional metabolic crosstalk between neurons and astrocytes in the mouse developing cortex. Neuron (2003) 37:275-86. doi:10.1016/S0896-6273(02)01170-4

195. Takatsuru Y, Iino M, Tanaka K, Ozawa S. Contribution of glutamate transporter GLT-1 to removal of synaptically released glutamate at climbing fiber-Purkinje cell synapses. Neurosci Lett (2007) 420:85-9. doi:10.1016/j.neulet.2007.04.062
196. Furness DN, Lehre KP. Immunocytochemical localization of a high-affinity glutamate-aspartate transporter, GLAST, in the rat and guinea-pig cochlea. Eur J Neurosci (1997) 9:1961-9. doi:10.1111/j.1460-9568.1997.tb00763.x

197. Takumi Y, Matsubara A, Danbolt NC, Laake JH, Storm-Mathisen J, Usami S, et al. Discrete cellular and subcellular localization of glutamine synthetase and the glutamate transporter GLAST in the rat vestibular end organ. Neuroscience (1997) 79:1137-44. doi:10.1016/S0306-4522(97)00025-0

198. Berger UV, Hediger MA. Distribution of the glutamate transporters GLAST and GLT-1 in rat circumventricular organs, meninges and dorsal root ganglia. J Comp Neurol (2000) 421:385-99. doi:10.1002/(SICI)1096-9861(20000605) 421:3<385::AID-CNE7>3.0.CO;2-S

199. Derouiche A, Rauen T. Coincidence of L-glutamate/L-aspartate transporter (GLAST) and glutamine synthetase (GS) immunoreactions in retinal glia: evidence for coupling of GLAST and GS in transmitter clearance. J Neurosci Res (1995) 42:131-43. doi:10.1002/jnr.490420115

200. Derouiche A. Possible role of the Müller cell in uptake and metabolism of glutamate in the mammalian outer retina. Vision Res (1996) 36:3875-8. doi:10.1016/S0042-6989(96)00140-X

201. Rauen T, Rothstein JD, Wassle H. Differential expression of three glutamate transporter subtypes in the rat retina. Cell Tissue Res (1996) 286:325-36. doi:10.1007/s004410050702

202. Lehre KP, Davanger S, Danbolt NC. Localization of the glutamate transporter protein GLAST in rat retina. Brain Res (1997) 744:129-37. doi:10.1016/S00068993(96)01022-0

203. Rauen T, Taylor WR, Kuhlbrodt K, Wiessner M. High-affinity glutamate transporters in the rat retina: a major role of the glial glutamate transporter GLAST-1 in transmitter clearance. Cell Tissue Res (1998) 291:19-31. doi:10.1007/s004410050976

204. Pow DV, Barnett NL. Changing patterns of spatial buffering of glutamate in developing rat retinae are mediated by the Muller cell glutamate transporter GLAST. Cell Tissue Res (1999) 297:57-66. doi:10.1007/s004410051333

205. Rauen T, Fischer F, Wiessner M. Glia-neuron interaction by high-affinity glutamate transporters in neurotransmission. Adv Exp Med Biol (1999) 468:81-95. doi:10.1007/978-1-4615-4685-6_7

206. Shashidharan P, Huntley GW, Murray JM, Buku A, Moran T, Walsh MJ, et al. Immunohistochemical localization of the neuron-specific glutamate transporter EAAC1 (EAAT3) in rat brain and spinal cord revealed by a novel monoclonal antibody. Brain Res (1997) 773:139-48. doi:10.1016/S0006-8993(97) 00921-9

207. Massie A, Cnops L, Smolders I, McCullumsmith R, Kooijman R, Kwak S, et al. High-affinity $\mathrm{Na}(+) / \mathrm{K}(+)$-dependent glutamate transporter EAAT4 is expressed throughout the rat fore- and midbrain. J Comp Neurol (2008) 511:155-72. doi:10.1002/cne.21823

208. de Vivo L, Melone M, Bucci G, Rothstein JD, Conti F. Quantitative analysis of EAAT4 promoter activity in neurons and astrocytes of mouse somatic sensory cortex. Neurosci Lett (2010) 474:42-5. doi:10.1016/j.neulet.2010.03.003

209. Gardiner RB, Ullensvang K, Danbolt NC, Caveney S, Donly BC. Cellular distribution of a high-affinity glutamate transporter in the nervous system of the cabbage looper Trichoplusia ni. J Exp Biol (2002) 205:2605-13.

210. Caveney S, Donly BC. Neurotransmitter transporters in the insect nervous system. Adv Insect Physiol (2002) 29:55-149. doi:10.1016/S0065-2806(02)29002-5

211. Bjørås M, Gjesdal O, Erickson JD, Torp R, Levy LM, Ottersen OP, et al. Cloning and expression of a neuronal rat brain glutamate transporter. Brain Res $\mathrm{Mol}$ Brain Res (1996) 36:163-8. doi:10.1016/0169-328X(95)00279-2

212. Berger UV, Hediger MA. Distribution of the glutamate transporters GLT-1 (SLC1A2) and GLAST (SLC1A3) in peripheral organs. Anat Embryol (Berl) (2006) 211:595-606. doi:10.1007/s00429-006-0109-x

213. Pollard M, McGivan J. The rat hepatoma cell line H4-II-E-C3 expresses high activities of the high-affinity glutamate transporter GLT-1A. FEBS Lett (2000) 484:74-6. doi:10.1016/S0014-5793(00)02114-1

214. Martinov V, Dehnes Y, Holmseth S, Shimamoto K, Danbolt NC, Valen G. A novel glutamate transporter blocker, LL-TBOA, attenuates ischaemic injury in the isolated, perfused rat heart despite low transporter levels. Eur J Cardiothorac Surg (2013). doi:10.1093/ejcts/ezt487

215. Lawton DM, Furness DN, Lindemann B, Hackney CM. Localization of the glutamate-aspartate transporter, GLAST, in rat taste buds. EurJ Neurosci (2000) 12:3163-71. doi:10.1046/j.1460-9568.2000.00207.x 
216. Gray C, Marie H, Arora M, Tanaka K, Boyde A, Jones S, et al. Glutamate does not play a major role in controlling bone growth. J Bone Miner Res (2001) 16:742-9. doi:10.1359/jbmr.2001.16.4.742

217. Torp R, Danbolt NC, Babaie E, Bjørås M, Seeberg E, Storm-Mathisen J, et al. Differential expression of two glial glutamate transporters in the rat brain: an in situ hybridization study. Eur J Neurosci (1994) 6:936-42. doi:10.1111/j.14609568.1994.tb00587.x

218. Schmitt A, Asan E, Puschel B, Jons T, Kugler P. Expression of the glutamate transporter GLT1 in neural cells of the rat central nervous system: nonradioactive in situ hybridization and comparative immunocytochemistry. Neuroscience (1996) 71:989-1004. doi:10.1016/0306-4522(95)00477-7

219. Torp R, Hoover F, Danbolt NC, Storm-Mathisen J, Ottersen OP. Differential distribution of the glutamate transporters GLT1 and rEAAC1 in rat cerebral cortex and thalamus: an in situ hybridization analysis. Anat Embryol (Berl) (1997) 195:317-26. doi:10.1007/s004290050051

220. Mennerick S, Dhond RP, Benz A, Xu WY, Rothstein JD, Danbolt NC, et al. Neuronal expression of the glutamate transporter GLT-1 in hippocampal microcultures. J Neurosci (1998) 18:4490-9.

221. Wang GJ, Chung HJ, Schnuer J, Pratt K, Zable AC, Kavanaugh MP, et al. High affinity glutamate transport in rat cortical neurons in culture. Mol Pharmacol (1998) 53:88-96.

222. Plachez C, Danbolt NC, Recasens M. Transient expression of the glial glutamate transporters GLAST and GLT in hippocampal neurons in primary culture. J Neurosci Res (2000) 59:587-93. doi:10.1002/(SICI)1097-4547(20000301)59: $5<587::$ AID-JNR1 > 3.0.CO;2-L

223. Yamada K, Watanabe M, Shibata T, Nagashima M, Tanaka K, Inoue Y. Glutamate transporter GLT-1 is transiently localized on growing axons of the mouse spinal cord before establishing astrocytic expression. J Neurosci (1998) 18:5706-13.

224. Rauen T, Kanner BI. Localization of the glutamate transporter GLT-1 in rat and macaque monkey retinae. Neurosci Lett (1994) 169:137-40. doi:10.1016/ 0304-3940(94)90375- 1

225. Euler T, Wassle H. Immunocytochemical identification of cone bipolar cells in the rat retina. J Comp Neurol (1995) 361:461-78. doi:10.1002/cne.903610310

226. Rauen T. Diversity of glutamate transporter expression and function in the mammalian retina. Amino Acids (2000) 19:53-62. doi:10.1007/s007260070033

227. Gundersen V, Danbolt NC, Ottersen OP, Storm-Mathisen J. Demonstration of glutamate/aspartate uptake activity in nerve endings by use of antibodies recognizing exogenous D-aspartate. Neuroscience (1993) 57:97-111. doi:10.1016/0306-4522(93)90114-U

228. Chen W, Mahadomrongkul V, Berger UV, Bassan M, DeSilva T, Tanaka $\mathrm{K}$, et al. The glutamate transporter GLT1a is expressed in excitatory axon terminals of mature hippocampal neurons. J Neurosci (2004) 24:1136-48. doi:10.1523/JNEUROSCI.1586-03.2004

229. Furness DN, Dehnes Y, Akhtar AQ, Rossi DJ, Hamann M, Grutle NJ, et al. A quantitative assessment of glutamate uptake into hippocampal synaptic terminals and astrocytes: new insights into a neuronal role for excitatory amino acid transporter 2 (EAAT2). Neuroscience (2008) 157:80-94. doi:10.1016/j.neuroscience.2008.08.043

230. Melone M, Bellesi M, Conti F. Synaptic localization of GLT-1a in the rat somatic sensory cortex. Glia (2009) 57:108-17. doi:10.1002/glia.20744

231. Melone M, Bellesi M, Ducati A, Iacoangeli M, Conti F. Cellular and synaptic localization of EAAT2a in human cerebral cortex. Front Neuroanat (2011) 4:151. doi:10.3389/fnana.2010.00151

232. de Vivo L, Melone M, Rothstein JD, Conti F. GLT-1 promoter activity in astrocytes and neurons of mouse hippocampus and somatic sensory cortex. Front Neuroanat (2010) 3:31. doi:10.3389/neuro.05.031.2009

233. Zhou Y, Wang XY, Tzingounis AV, Danbolt NC, Larsson HP. Modeling of glutamate transporters reconstituted in liposomes argues against heteroexchange being substantially faster than net uptake. Soc Neurosci Abstr (2013) 2013:703.05.

234. Sun Y, Petr GT, Frederick NM, Aoki CJ, Rotenberg A, Dhamne SC, et al. Celltype specific expression and function of the glutamate transporter GLT-1 at excitatory synapses probed with conditional deletion. Soc Neurosci Abstr (2012) 2012:332.16.

235. Berger UV, Desilva TM, Chen WZ, Rosenberg PA. Cellular and subcellular mRNA localization of glutamate transporter isoforms GLT1a and GLT1b in rat brain by in situ hybridization. J Comp Neurol (2005) 492:78-89. doi:10.1002/cne.20737
236. Chiu C-S, Jensen K, Sokolova I, Wang D, Li M, Deshpande P, et al. Number, density, and surface/cytoplasmic distribution of GABA transporters at presynaptic structures of knock-in mice carrying GABA transporter subtype 1-green fluorescent protein fusions. J Neurosci (2002) 22:10251-66.

237. Liu GX, Liu SA, Cai GQ, Sheng ZJ, Cai YQ, Jiang J, et al. Reduced aggression in mice lacking GABA transporter subtype 1. J Neurosci Res (2007) 85:649-55. doi:10.1002/jnr.21148

238. Xu YF, Cai YQ, Cai GQ, Jiang J, Sheng ZJ, Wang ZG, et al. Hypoalgesia in mice lacking GABA transporter subtype 1. J Neurosci Res (2008) 86:465-70. doi:10.1002/jnr.21499

239. Liu GX, Cai GQ, Cai YQ, Sheng ZJ, Jiang J, Mei ZT, et al. Reduced anxiety and depression-like behaviors in mice lacking GABA transporter subtype I. Neuropsychopharmacology (2007) 32:1531-9. doi:10.1038/sj.npp. 1301281

240. Cai YQ, Cai GQ, Liu GX, Cai Q, Shi JH, Shi J, et al. Mice with genetically altered GABA transporter subtype 1 (GAT1) expression show altered behavioral responses to ethanol. J Neurosci Res (2006) 84:255-67. doi:10.1002/jnr.20884

241. Jensen K, Chiu C-S, Sokolova I, Lester HA, Mody I. GABA transporter1 (GAT1)-deficient mice: differential tonic activation of GABA(A) versus GABA(B) receptors in the hippocampus. J Neurophysiol (2003) 90:2690-701. doi:10.1152/jn.00240.2003

242. Chiu C-S, Brickley S, Jensen K, Southwell A, McKinney S, Cull-Candy S, et al. GABA transporter deficiency causes tremor, ataxia, nervousness, and increased GABA-induced tonic conductance in cerebellum. J Neurosci (2005) 25:3234-45. doi:10.1523/JNEUROSCI.3364-04.2005

243. Vossler DG, Morris GL, Harden CL, Montouris G, Faught E, Kanner AM, et al. Tiagabine in clinical practice: effects on seizure control and behavior. Epilepsy Behav (2013) 28:211-6. doi:10.1016/j.yebeh.2013.05.006

244. Thoeringer CK, Ripke S, Unschuld PG, Lucae S, Ising M, Bettecken T, et al. The GABA transporter 1 (SLC6A1): a novel candidate gene for anxiety disorders. J Neural Transm (2009) 116:649-57. doi:10.1007/s00702-008-0075-y

245. Lauriat TL, McInnes LA. EAAT2 regulation and splicing: relevance to psychiatric and neurological disorders. Mol Psychiatry (2007) 12:1065-78. doi:10. 1038/sj.mp.4002065

246. Bröer S, Palacin M. The role of amino acid transporters in inherited and acquired diseases. Biochem J (2011) 436:193-211. doi:10.1042/BJ20101912

247. Mitani A, Tanaka K. Functional changes of glial glutamate transporter GLT-1 during ischemia: an in vivo study in the hippocampal CAl of normal mice and mutant mice lacking GLT-1. J Neurosci (2003) 23:7176-82.

248. Takasaki C, Okada R, Mitani A, Fukaya M, Yamasaki M, Fujihara Y, et al. Glutamate transporters regulate lesion-induced plasticity in the developing somatosensory cortex. J Neurosci (2008) 28:4995-5006. doi:10.1523/ JNEUROSCI.0861-08.2008

249. Ullensvang K, Lehre KP, Storm-Mathisen J, Danbolt NC. Differential developmental expression of the two rat brain glutamate transporter proteins GLAST and GLT. Eur J Neurosci (1997) 9:1646-55. doi:10.1111/j.1460-9568.1997. tb01522.x

250. Furuta A, Rothstein JD, Martin LJ. Glutamate transporter protein subtypes are expressed differentially during rat CNS development. J Neurosci (1997) 17:8363-75

251. Hertz L. The glutamate-glutamine (GABA) cycle: importance of late postnatal development and potential reciprocal interactions between biosynthesis and degradation. Front Endocrinol (Lausanne) (2013) 4:59. doi:10.3389/fendo. 2013.00059

252. Lepore A, O’Donnell J, Kim A, Yang E, Tuteja A, Haidet-Phillips A, et al. Reduction in expression of the astrocyte glutamate transporter, GLT1, worsens functional and histological outcomes following traumatic spinal cord injury. Glia (2011) 59:1996-2005. doi:10.1002/glia.21241

253. Trotti D, Rolfs A, Danbolt NC, Brown RH Jr, Hediger MA. SOD1 mutants linked to amyotrophic lateral sclerosis selectively inactivate a glial glutamate transporter. Nat Neurosci (1999) 2:427-33. doi:10.1038/8091

254. Trotti D, Aoki M, Pasinelli P, Berger UV, Danbolt NC, Brown RH Jr, et al. Amyotrophic lateral sclerosis-linked glutamate transporter mutant has impaired glutamate clearance capacity. J Biol Chem (2001) 276:576-82. doi:10.1074/jbc. M003779200

255. Foley PF, Loh EW, Innes DJ, Williams SM, Tannenberg AE, Harper CG, et al. Association studies of neurotransmitter gene polymorphisms in alcoholic Caucasians. Ann N Y Acad Sci (2004) 1025:39-46. doi:10.1196/annals.1316.005 
256. Deng X, Shibata H, Ninomiya H, Tashiro N, Iwata N, Ozaki N, et al. Association study of polymorphisms in the excitatory amino acid transporter 2 gene (SLC1A2) with schizophrenia. BMC Psychiatry (2004) 4:21. doi:10.1186/1471244X-4-21

257. dos Santos VA, Chatkin JM, Bau CH, Paixao-Cortes VR, Sun Y, Zamel N, et al. Glutamate and synaptic plasticity systems and smoking behavior: results from a genetic association study. PLoS One (2012) 7:e38666. doi:10.1371/journal. pone.0038666

258. Thier S, Lorenz D, Nothnagel M, Poremba C, Papengut F, Appenzeller S, et al. Polymorphisms in the glial glutamate transporter SLC1A2 are associated with essential tremor. Neurology (2012) 79:243-8. doi:10.1212/WNL. 0b013e31825fdeed

259. Dallaspezia S, Poletti S, Lorenzi C, Pirovano A, Colombo C, Benedetti F. Influence of an interaction between lithium salts and a functional polymorphism in SLC1A2 on the history of illness in bipolar disorder. Mol Diagn Ther (2012) 16:303-9. doi:10.1007/s40291-012-0004-5

260. Watase K, Hashimoto K, Kano M, Yamada K, Watanabe M, Inoue Y, et al. Motor discoordination and increased susceptibility to cerebellar injury in GLAST mutant mice. Eur J Neurosci (1998) 10:976-88. doi:10.1046/j.1460-9568.1998. 00108.x

261. Hakuba N, Koga K, Gyo K, Usami SI, Tanaka K. Exacerbation of noise-induced hearing loss in mice lacking the glutamate transporter GLAST. JNeurosci (2000) 20:8750-3.

262. Harada T, Harada C, Watanabe M, Inoue Y, Sakagawa T, Nakayama N, et al. Functions of the two glutamate transporters GLAST and GLT-1 in the retina. Proc Natl Acad Sci U S A (1998) 95:4663-6. doi:10.1073/pnas.95.8.4663

263. Stoffel W, Korner R, Wachtmann D, Keller BU. Functional analysis of glutamate transmission of GLAST1 and transporters in excitatory synaptic GLAST1/EAAC1 deficient mice. Brain Res Mol Brain Res (2004) 128:170-81. doi:10.1016/j.molbrainres.2004.06.026

264. Karlsson R-M, Tanaka K, Saksida LM, Bussey TJ, Heilig M, Holmes A. Assessment of glutamate transporter GLAST (EAAT1)-deficient mice for phenotypes relevant to the negative and executive/cognitive symptoms of schizophrenia. Neuropsychopharmacology (2009) 34:1578-89. doi:10.1038/npp.2008. 215

265. Karlsson R-M, Adermark L, Molander A, Perreau-Lenz S, Singley E, Solomon $\mathrm{M}$, et al. Reduced alcohol intake and reward associated with impaired endocannabinoid signaling in mice with a deletion of the glutamate transporter GLAST. Neuropharmacology (2012) 63:181-9. doi:10.1016/j.neuropharm. 2012.01.027

266. Watanabe T, Morimoto K, Hirao T, Suwaki H, Watase K, Tanaka K. Amygdala-kindled and pentylenetetrazole-induced seizures in glutamate transporter GLAST-deficient mice. Brain Res (1999) 845:92-6. doi:10.1016/S00068993(99)01945-9

267. Jen JC, Wan J, Palos TP, Howard BD, Baloh RW. Mutation in the glutamate transporter EAAT1 causes episodic ataxia, hemiplegia, and seizures. Neurology (2005) 65:529-34. doi:10.1212/01.wnl.0000172638.58172.5a

268. de Vries B, Mamsa H, Stam AH, Wan J, Bakker SL, Vanmolkot KR, et al. Episodic ataxia associated with EAAT1 mutation $\mathrm{C} 186 \mathrm{~S}$ affecting glutamate reuptake. Arch Neurol (2009) 66:97-101. doi:10.1001/archneurol.2008.535

269. Peghini P, Janzen J, Stoffel W. Glutamate transporter EAAC-1-deficient mice develop dicarboxylic aminoaciduria and behavioral abnormalities but no neurodegeneration. EMBO J (1997) 16:3822-32. doi:10.1093/emboj/16.13. 3822

270. Aoyama K, Suh SW, Hamby AM, Liu J, Chan WY, Chen Y, et al. Neuronal glutathione deficiency and age-dependent neurodegeneration in the EAAC1 deficient mouse. Nat Neurosci (2006) 9:119-26. doi:10.1038/nn1609
271. Berman AE, Chan WY, Brennan AM, Reyes RC, Adler BL, Suh SW, et al. Nacetylcysteine prevents loss of dopaminergic neurons in the EAAC1(-/-) mouse. Ann Neurol (2011) 69:509-20. doi:10.1002/ana.22162

272. Bailey CG, Ryan RM, Thoeng AD, Ng C, King K, Vanslambrouck JM, et al. Loss-of-function mutations in the glutamate transporter SLC1A1 cause human dicarboxylic aminoaciduria. J Clin Invest (2011) 121:446-53. doi:10.1172/ JCI44474

273. Brandl EJ, Muller DJ, Richter MA. Pharmacogenetics of obsessive-compulsive disorders. Pharmacogenomics (2012) 13:71-81. doi:10.2217/pgs.11.133

274. Walitza S, Wendland JR, Gruenblatt E, Warnke A, Sontag TA, Tucha O, et al. Genetics of early-onset obsessive-compulsive disorder. Eur Child Adolesc Psychiatry (2010) 19:227-35. doi:10.1007/s00787-010-0087-7

275. Ventura R, Harris KM. Three-dimensional relationships between hippocampal synapses and astrocytes. J Neurosci (1999) 19:6897-906.

276. Lee TS, Bjørnsen LP, Paz C, Kim JH, Spencer SS, Spencer DD, et al. GAT1 and GAT3 expression are differently localized in the human epileptogenic hippocampus. Acta Neuropathol (2006) 111:351-63. doi:10.1007/s00401-0050017-9

277. Borden LA, Smith KE, Hartig PR, Branchek TA, Weinshank RL. Molecular heterogeneity of the gamma-aminobutyric acid (GABA) transport system. J Biol Chem (1992) 267:21098-104.

278. Clark JA, Deutch AY, Gallipoli PZ, Amara SG. Functional expression and CNS distribution of a beta-alanine-sensitive neuronal GABA transporter. Neuron (1992) 9:337-48. doi:10.1016/0896-6273(92)90172-A

279. Smith KE, Borden LA, Wang C-H, Hartig PR, Branchek TA, Weinshank RL. Cloning and expression of a high affinity taurine transporter from rat brain. Mol Pharmacol (1992) 42:563-9.

280. Liu QR, López-Corcuera B, Nelson H, Mandiyan S, Nelson N. Cloning and expression of a cDNA encoding the transporter of taurine and betaalanine in mouse brain. Proc Natl Acad Sci U S A (1992) 89:12145-9. doi:10.1073/pnas.89.24.12145

281. Bröer S. Amino acid transport across mammalian intestinal and renal epithelia. Physiol Rev (2008) 88:249-86. doi:10.1152/physrev.00018.2006

282. Larsen M, Larsen BB, Frolund B, Nielsen CU. Transport of amino acids and GABA analogues via the human proton-coupled amino acid transporter, hPAT1: characterization of conditions for affinity and transport experiments in Caco-2 cells. Eur J Pharm Sci (2008) 35:86-95. doi:10.1016/j.ejps.2008.06.007

283. Hediger MA, Clemencon B, Burrier RE, Bruford EA. The ABCs of membrane transporters in health and disease (SLC series): introduction. Mol Aspects Med (2013) 34:95-107. doi:10.1016/j.mam.2012.12.009

Conflict of Interest Statement: The authors declare that the research was conducted in the absence of any commercial or financial relationships that could be construed as a potential conflict of interest.

Received: 05 October 2013; paper pending published: 16 October 2013; accepted: 17 October 2013; published online: 11 November 2013.

Citation: Zhou Y and Danbolt NC (2013) GABA and glutamate transporters in brain. Front. Endocrinol. 4:165. doi: 10.3389/fendo.2013.00165

This article was submitted to Cellular Endocrinology, a section of the journal Frontiers in Endocrinology.

Copyright (c) 2013 Zhou and Danbolt. This is an open-access article distributed under the terms of the Creative Commons Attribution License (CC BY). The use, distribution or reproduction in other forums is permitted, provided the original author (s) or licensor are credited and that the original publication in this journal is cited, in accordance with accepted academic practice. No use, distribution or reproduction is permitted which does not comply with these terms. 